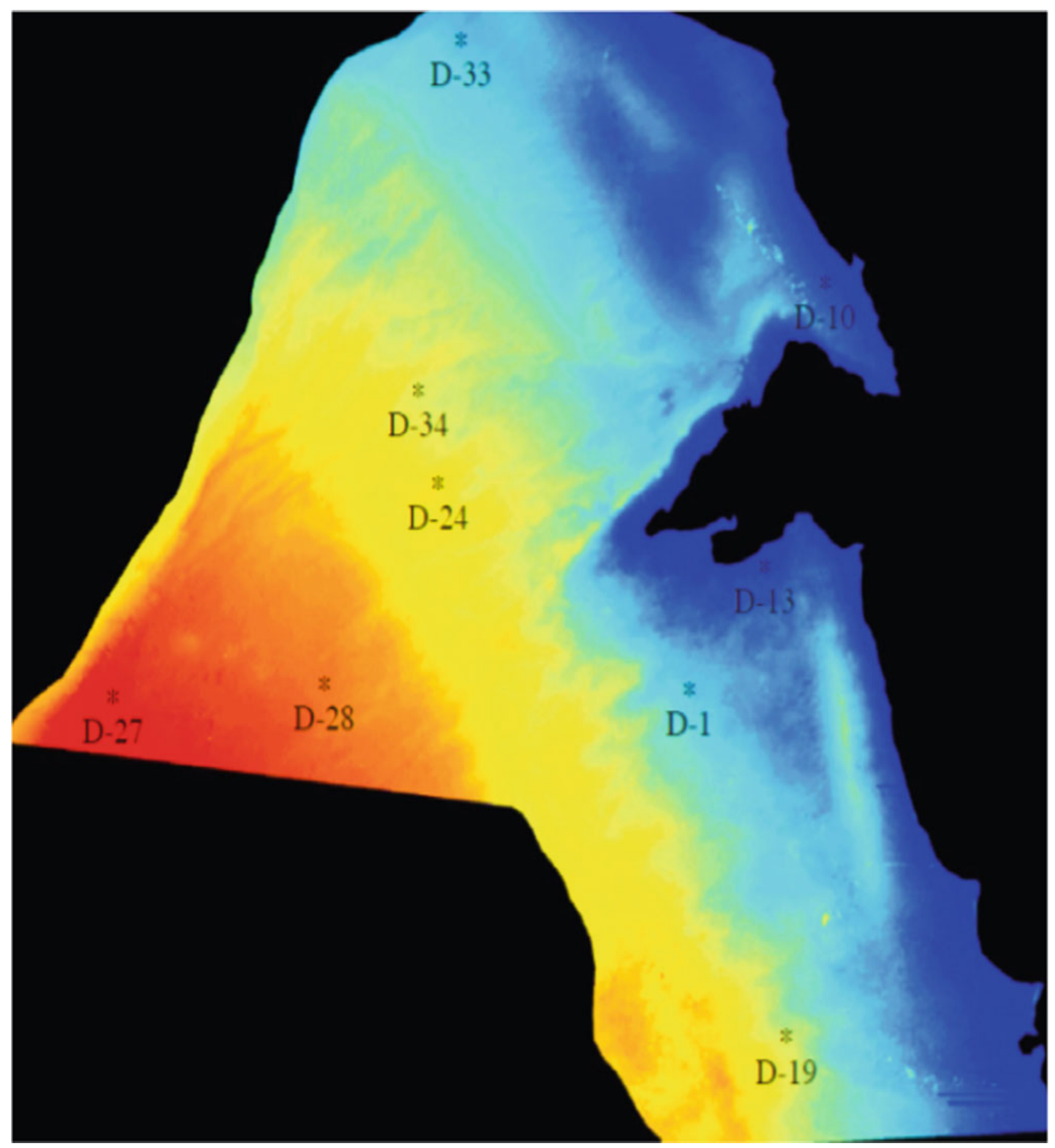




\title{
Deposited Rates of Radionuclides
}

\author{
Abdulaziz Aba, Anfal Ismaeel, Aisha Al-Boloushi, Hanadi Al-Shimary, \\ and Omar Al-Boloushi
}

\begin{abstract}
- Temporal and Spatial Distribution of Radionuclides in Dust Fallout.

- The depositional fluxes of the natural radionuclides $\left({ }^{40} \mathrm{~K}\right.$, ${ }^{210} \mathrm{~Pb}$, and $\left.{ }^{7} \mathrm{Be}\right)$ and the man-made radionuclides $\left({ }^{137} \mathrm{Cs}\right)$ have been calculated using efficiency calibrated ultra-low background gamma spectrometry in nine sampling sites covering Kuwait.

- Maps showing high and low concentrations of radionuclides distribution among Kuwait.
\end{abstract}

\section{Radionuclides}

\section{Methodology}

\section{Temporal and Spatial Distribution of Radionuclides in Dust Fallout}

The depositional fluxes of the natural radionuclides $\left({ }^{40} \mathrm{~K}\right.$, ${ }^{210} \mathrm{~Pb}$, and $\left.{ }^{7} \mathrm{Be}\right)$ and the man-made radionuclides $\left({ }^{137} \mathrm{Cs}\right)$ were calculated using efficiency-calibrated ultralow

\footnotetext{
O. Al-Boloushi e-mail: aaba@kisr.edu.kw

A. Ismaeel

e-mail: aismaeel@kisr.edu.kw

A. Al-Boloushi

e-mail: aboloushi@kisr.edu.kw

H. Al-Shimary

e-mail: hshammari@kisr.edu.kw

O. Al-Boloushi

e-mail: oboloushi@kisr.edu.kw
}

A. Aba $(\bowtie) \cdot A$. Ismaeel - A. Al-Boloushi · H. Al-Shimary ·

Crisis Decision Supports Program (CDS), Environment and Life Sciences Research Center (ELSRC), Kuwait Institute for Scientific Research (KISR), P.O. Box 2488513109 Safat, Kuwait background gamma spectrometry in nine sampling sites covering Kuwait (Fig. 6.1). The dust fallout samples were collected on a monthly basis. Four collectors were installed in each sampling location to collect the adequate sample mass required for radioactivity analysis. The composite samples were subjected to long counting times regarding attaining an acceptable detection limit and to resolve very low-intensity peaks.

The collected gamma spectra were analyzed by Genie-2000 (Canberra Inc, USA) using the spectral lines of the most intense gamma energy lines. The decay correction and building-up factor of ${ }^{7} \mathrm{Be}$ during the sampling period (almost 30 days) were considered due to the relatively short half life of ${ }^{7} \mathrm{Be}$. The concentration of radionuclides in dry deposition fluxes $\left(\mathrm{Bq} \mathrm{m}{ }^{-2}\right)$ per month was determined by multiplying their specific activities in $\mathrm{Bq} \mathrm{g}^{-1}$ with the weight per unit area of the collector $\left(\mathrm{g} \mathrm{m}^{-2}\right)$ during sampling time (30 days).

The variety of all of the calculated radionuclides and depositional fluxes revealed a temporal tendency (i.e., highest in the spring months [February, March, April], when the precipitation rates are highest, and hence, more dust is washed out and the lowest in October-November of each year) (Fig. 6.2). The correlation of depositional dust fallout and the radionuclides fluxes was in the order of ${ }^{40} \mathrm{~K} ;{ }^{137} \mathrm{Cs}$;

${ }^{210} \mathrm{~Pb}$ and ${ }^{7} \mathrm{Be}$. The strongest correlation was with the terrestrial origin ${ }^{40} \mathrm{~K}(0.92)$, and the weakest was with the cosmogenic origin ${ }^{7} \mathrm{Be}(0.67)$.

On the other hand, the spatial distributions of radionuclide depositional fluxes showed a site-dependent relationship that is similar to the spatial dust fallout: highest in the interior areas and gradually decreasing along the coastal line. Nevertheless, an exception of the cosmogenic radionuclide ${ }^{7} \mathrm{Be}$ distribution was observed in some months because of possibly different climatologically conditions.

The averages of the depositional fluxes of similar months were gridded using the GIS (ArcGIS) software package and presented as averages on a monthly basis from October 2009 to August 2011. 


\section{Monthly spatial distribution of ${ }^{7} \mathrm{Be}$}

Figures 6.3, 6.4, 6.5, 6.6, 6.7, 6.8, 6.9, 6.10, 6.11, 6.12, 6.13, 6.14 and 6.15 show the annual and monthly spatial deposition rates of the ${ }^{7} \mathrm{Be}$ radionuclide in dust fallout during October 2009-October 2011. The minimum monthly deposition fluxes $\left(2.4 \mathrm{~Bq} \mathrm{~m}^{-2}\right)$ were observed in December, when the precipitation was the lowest. In contrast, the high concentration during the spring season (March-April-May) was due to rainfall during the period supporting the theory of wet precipitation commonly associated with the mixing of stratospheric and tropospheric air masses (Daish et al. 2005). In spring time, a rapid removal from lower polar troposphere to the troposphere at the northern hemisphere is well known (UNSCEAR 2000) and, possibly due to the folding of the troposphere during April and May at mid-latitude (30-50), enhances the removal of the stratospheric ${ }^{7} \mathrm{Be}$ into the troposphere (Viezee and Singh 1980; Kritz et al. 1991). However, in contrast, the spatial distribution in the fall months (September-October-November) might be due to the effect of southeasterly wind contribution. The highest monthly readings (76.5 and $184 \mathrm{~Bq} \mathrm{~m}^{-2}$ ) were observed in January and April, respectively, due to the effect of a washout by precipitation.

\section{Temporal, spatial distribution of ${ }^{137} \mathrm{Cs}$}

${ }^{137} \mathrm{Cs}$ is a human-made radionuclide with a half life of 30 years. It was produced during the atmospheric testing of thermonuclear weapons in the period extending from the mid-1950s to the 1980s. Global fallout of ${ }^{137} \mathrm{Cs}$ began in 1954, peaked in the early 1960s and subsequently decreased, reaching near-zero levels in the mid-1980s. Fallout levels were globally variable, reflecting both annual precipitation amount and location relative to the main weapons tests (Walling 2002). Smaller amounts of ${ }^{137} \mathrm{Cs}$ have been released into the atmosphere by catastrophes at nuclear power plants, notably the Chernobyl disaster in 1986, which resulted in additional outputs of ${ }^{137} \mathrm{Cs}$ fallout over large areas of Europe and adjacent regions. However, wide measurements of ${ }^{137} \mathrm{Cs}$ concentration have also been carried out in Kuwaiti aerosol, in cooperation with the Comprehensive Nuclear Test Ban Treaty (CTBT) from 1995 to 1999. The reported ${ }^{137} \mathrm{Cs}$ concentration in the air was between 1.44 and 107.84 , with an average value of $10.6 \mu \mathrm{Bq} \mathrm{m}^{-3}$ (Biegalski et al. 2001).

Figures 6.16, 6.17, 6.18, 6.19, 6.20, 6.21, 6.22, 6.23, $6.24,6.25,6.26,6.27$ and 6.28 illustrate the annual and monthly spatial deposition rates of ${ }^{137} \mathrm{Cs}$, which display similar behavior to ${ }^{210} \mathrm{~Pb}$ and ${ }^{7} \mathrm{Be}$ variations. The correlation coefficients of ${ }^{137} \mathrm{Cs} /{ }^{210} \mathrm{~Pb}$ and ${ }^{137} \mathrm{Cs} /{ }^{7} \mathrm{Be}$ were 0.87 and 0.94 , respectively. The average monthly deposition rates varied from 0.02 to $4.18 \mathrm{~Bq} \mathrm{~m}^{-2}$, while the annual deposition rates varied from 0.2 to $50.21 \mathrm{~Bq} \mathrm{~m}^{-2}$. Based on the previous observations (e.g., the influence of precipitation, wind direction, and depositional dust rates), the dominant source of ${ }^{137} \mathrm{Cs}$ fallout is the transportation of dust by the northwesterly wind, as the areas of northern Europe and eastern Mediterranean are most affected by ${ }^{137} \mathrm{Cs}$ fallout (nuclear bomb tests and Chernobyl accident), more so than the Gulf Region.

\section{Temporal, spatial distribution of ${ }^{40} \mathrm{~K}$}

Figures 6.29, 6.30, 6.31, 6.32, 6.33, 6.34, 6.35, 6.36, 6.37, $6.38,6.39,6.40$ and 6.41 illustrate the annual and monthly spatial deposition rates of ${ }^{40} \mathrm{~K}$ radionuclide in dust fallout. The highest ${ }^{40} \mathrm{~K}$ concentrations were observed in spring months, when it reached a maximum in March 2011 $\left(96.27 \mathrm{~Bq} \mathrm{~m}^{-2}\right)$ and the lowest in fall $\left(1.8 \mathrm{~Bq} \mathrm{~m}^{-2}\right)$, which is quite consistent with the dust loadings of the corresponding months. The annual variations of ${ }^{40} \mathrm{~K}$ concentration in dust fallout varied from 74 to $557 \mathrm{~Bq} \mathrm{~m}^{-2}$, as presented in Fig. 6.29. This quantity of the ${ }^{40} \mathrm{~K}$ deposition rate corresponds to about $412 \mathrm{~Bq} \mathrm{~kg}^{-1}$ and the average measured ${ }^{40} \mathrm{~K}$ concentration in Kuwaiti soil is $365 \mathrm{~Bq} \mathrm{~kg}^{-1}$, which is similar to the worldwide average concentration (420 Bq kg ${ }^{-1)}$ (UNSCEAR 2000). The distribution of ${ }^{40} \mathrm{~K}$ monthly and seasonal variations displays similar behavior to the dust fallout trend. However, the site specificity of ${ }^{40} \mathrm{~K}$ is very similar to the dust deposition distribution, which is very low in the coastal zone, significantly increasing in the southwest of the country.

\section{Temporal, spatial distribution of ${ }^{210} \mathrm{~Pb}$}

Figures $6.42,6.43,6.44,6.45,6.46,6.47,6.48,6.49,6.50$, $6.51,6.52,6.53$ and 6.54 illustrate the annual and monthly spatial deposition rates of ${ }^{210} \mathrm{~Pb}$ radionuclide in dust fallout from October 2009 to October 2011. The highest ${ }^{210} \mathrm{~Pb}$ concentrations were observed in spring $\left(41.4 \mathrm{~Bq} \mathrm{~m}^{-2}\right)$ and the lowest in fall $\left(1.8 \mathrm{~Bq} \mathrm{~m}^{-2}\right)$, which is quite consistent with the dust loadings of the corresponding months. However, the wet precipitation associated with Sarrayat and Koss played a major role in obtaining these high deposition fluxes (Aba et al. 2016, 2018; Al-Dousari et al. 2016). The monthly deposition ratios of ${ }^{7} \mathrm{Be}$ and ${ }^{210} \mathrm{~Pb}$ are largely consistent with the dust loading in the corresponding months. However, an extreme deposition rate $\left(63 \mathrm{~Bq} \mathrm{~m}^{-2}\right)$ was observed in March 2011, when an exotic storm hit Kuwait. 


\section{Samples Locations}

Figure 6.1.

\section{Temporal Variations of Radionuclides}

Figure 6.2.

\section{Annual Deposited Rates of ${ }^{7} \mathrm{Be}$}

The average annual ${ }^{7} \mathrm{Be}$ deposited rates in Kuwait from October 2009 to August 2011 varied from 339 to $481 \mathrm{~Bq}$ $\mathrm{m}^{-2}$, with an average similar $\left(422 \mathrm{~Bq} \mathrm{~m}^{-2}\right)$ to the reported data of the global model $\left(400 \mathrm{~Bq} \mathrm{~m}^{-2}\right)$. The maximum rates were found in a transect width of about $50 \mathrm{~km}$ from north to south. The minimum rates were shown along the transect from the middle of the country down to the southeastern part. The dominant annual wind direction is northwesterly (Fig. 6.3).

\begin{tabular}{l|l}
\hline $\begin{array}{l}\text { Areas with high radionuclide } \\
\text { concentration }\end{array}$ & $\begin{array}{l}\text { Areas with low radionuclide } \\
\text { concentration }\end{array}$ \\
\hline Abdulli & Sulaybiyah \\
Ratqah & Wafra Farms \\
Dibdibah & KhurFawaris \\
Um Al Madafi & Khiran \\
Liyah & Qurain \\
\hline
\end{tabular}

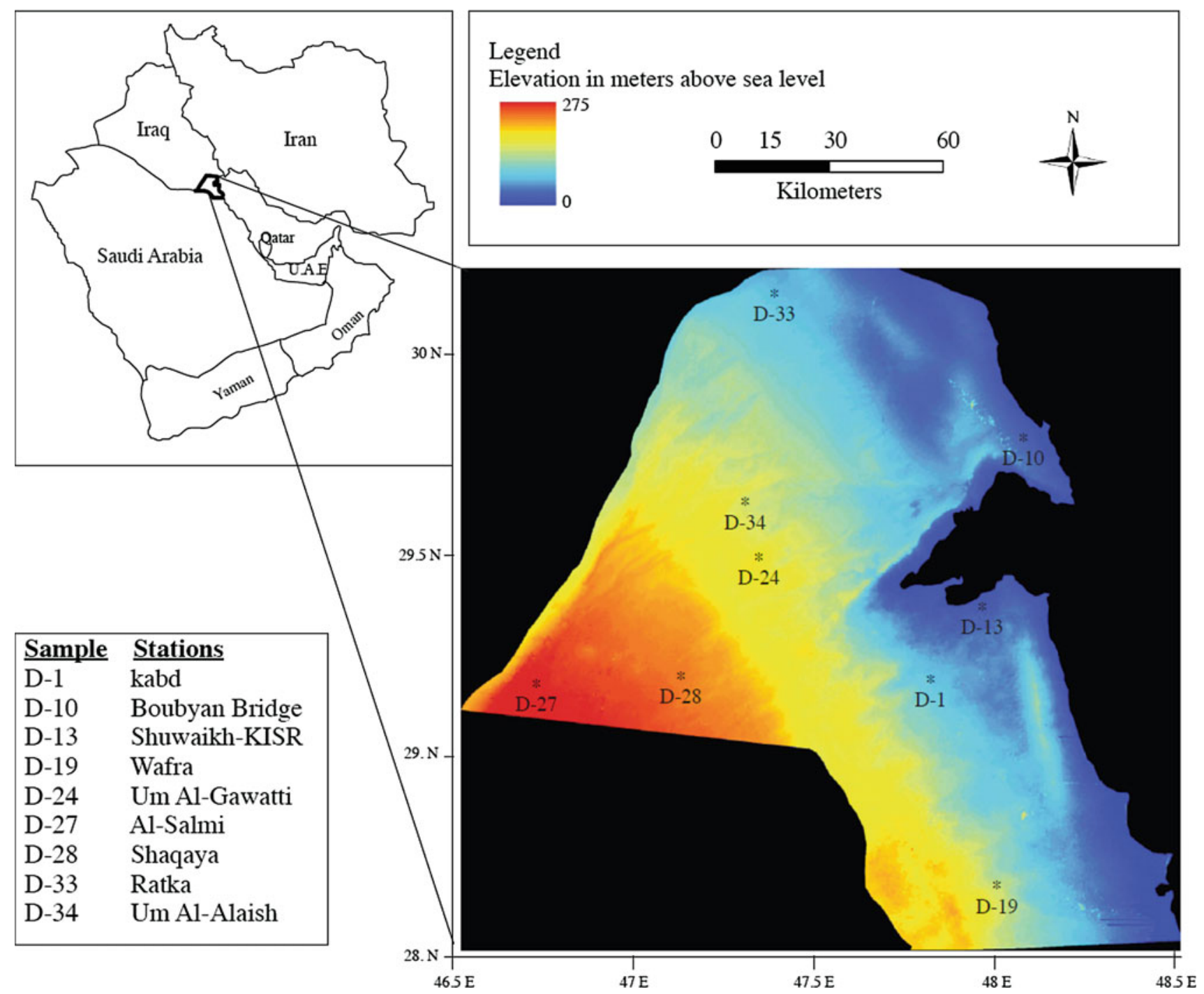

Fig. 6.1 Sampling locations of dust fallout and digital elevation model of Kuwait using ASTER stereo data 
Fig. 6.2 Temporal variations of radionuclide depositional fluxes in Kuwait

Fig. 6.3 Average deposited rates of ${ }^{7} \mathrm{Be}$
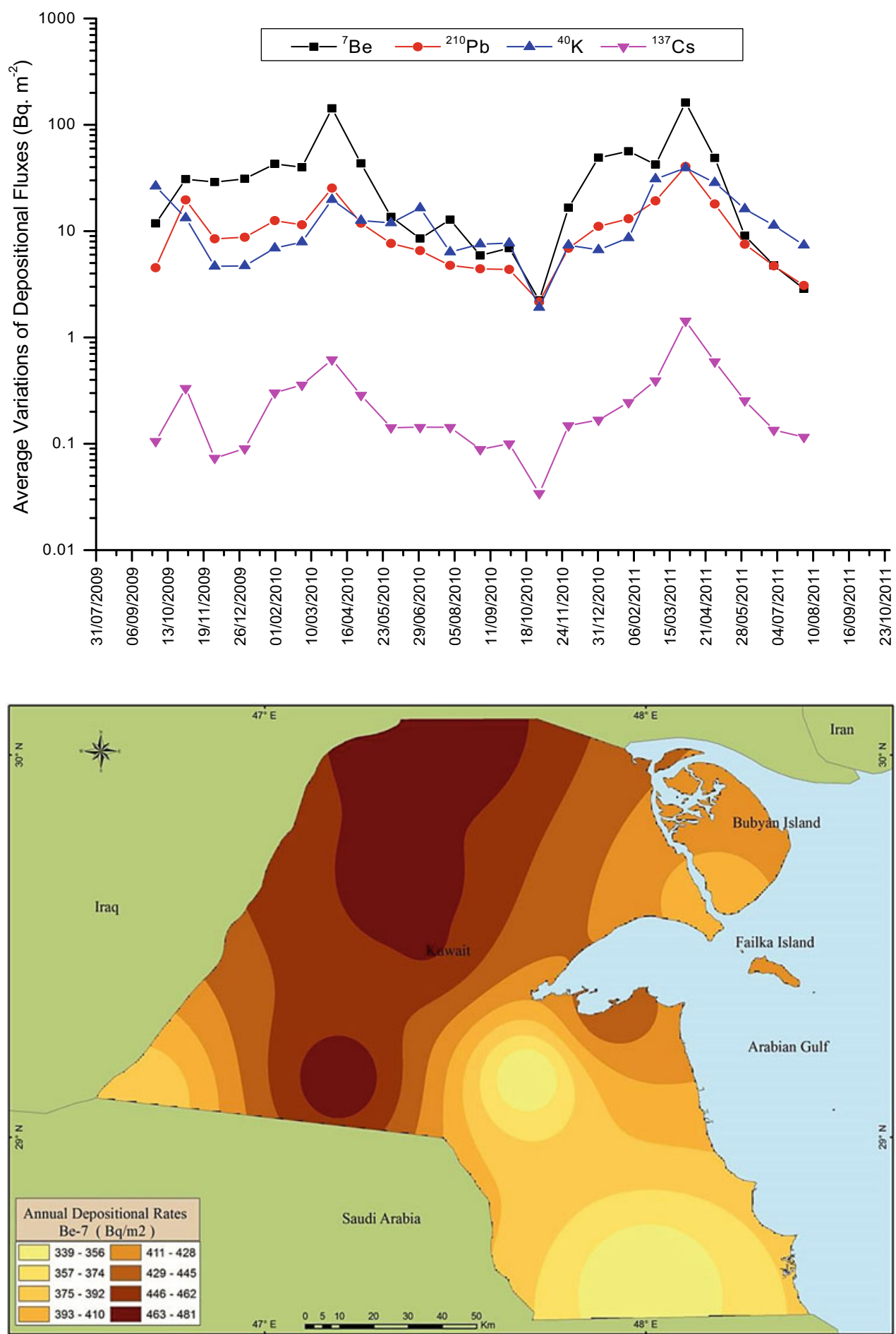

\section{Monthly Deposited Rates of ${ }^{7} \mathrm{Be}$}

The monthly ${ }^{7} \mathrm{Be}$ deposited rates in Kuwait January 2010 2011 reveal a range from 13.6 to $76.5 \mathrm{~Bq} \mathrm{~m}^{-2}$, with the maximum in northern areas and the lowest in southern areas. The predominant wind direction for this month was north-

\begin{tabular}{l|l}
\hline $\begin{array}{l}\text { Areas with high radionuclide } \\
\text { concentration }\end{array}$ & $\begin{array}{l}\text { Areas with low radionuclide } \\
\text { concentration }\end{array}$ \\
\hline Abdulli & Salmi \\
Ratqah & Sulaybiyah \\
Um Eish & Wafra Farms \\
Raudhatain & KhurFawaris \\
Huwaymilyah & Khiran
\end{tabular}
westerly (Fig. 6.4). 
Fig. 6.4 Average deposited rates of ${ }^{7} \mathrm{Be}$ in January (2010-2011)

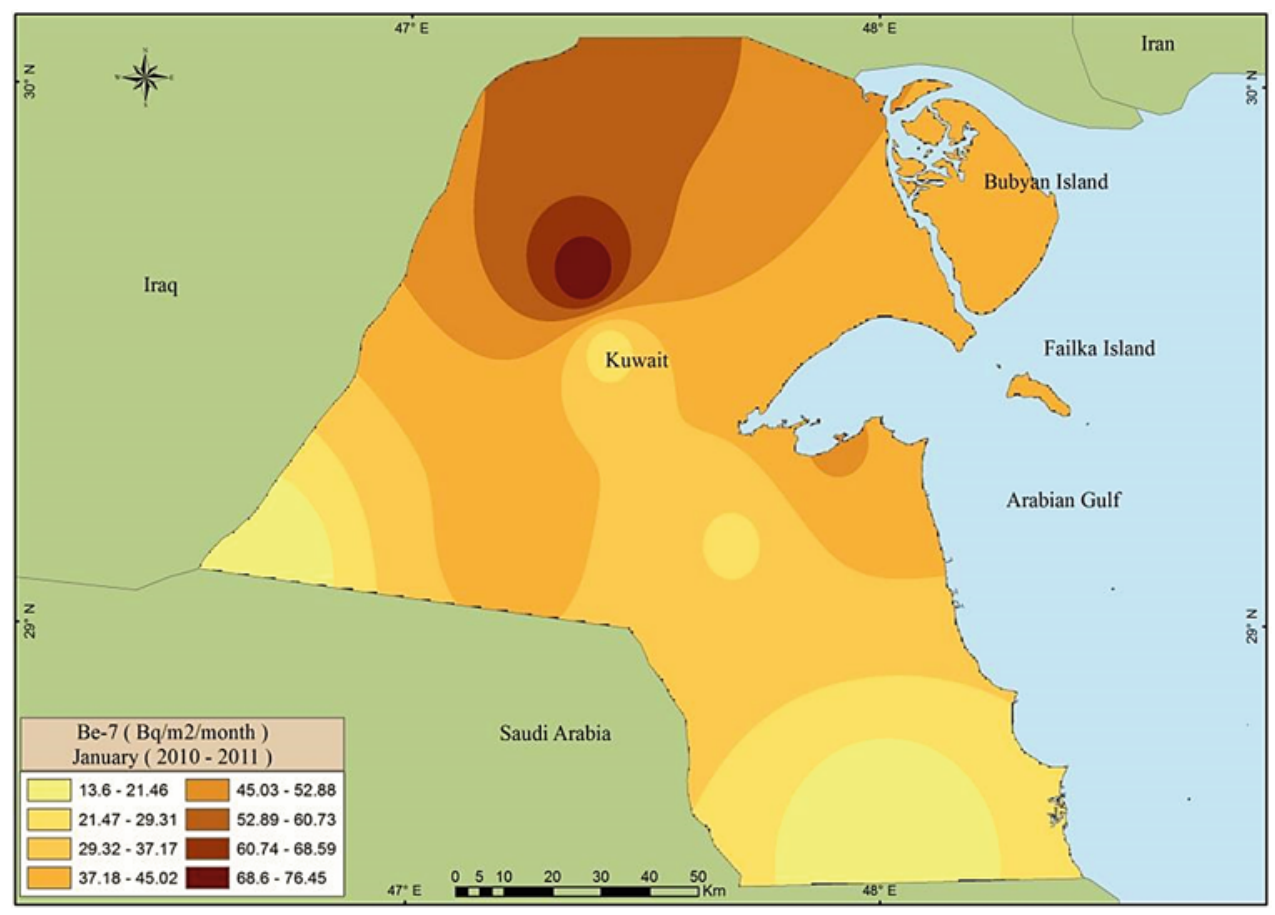

The monthly rates at which ${ }^{7}$ Be were deposited in Kuwait in February 2010-2011 which reveal a range from 36.08 to $63.83 \mathrm{~Bq} \mathrm{~m}^{-2}$, with three maximum spots. This possibly happened because of the effect of dust storms this month. The predominant wind direction for this month was northwesterly (Fig. 6.5).
Areas with high radionuclide concentration

Bubiyan Bridge

Dibdibah

Wafra Farms

KhurFawaris

Subiyah
Areas with low radionuclide concentration

Salmi

Um Al Madafi'

Liyah

Shegaya

Um Eish

Fig. 6.5 Average deposited rates of ${ }^{7}$ Be in February (2010-2011)

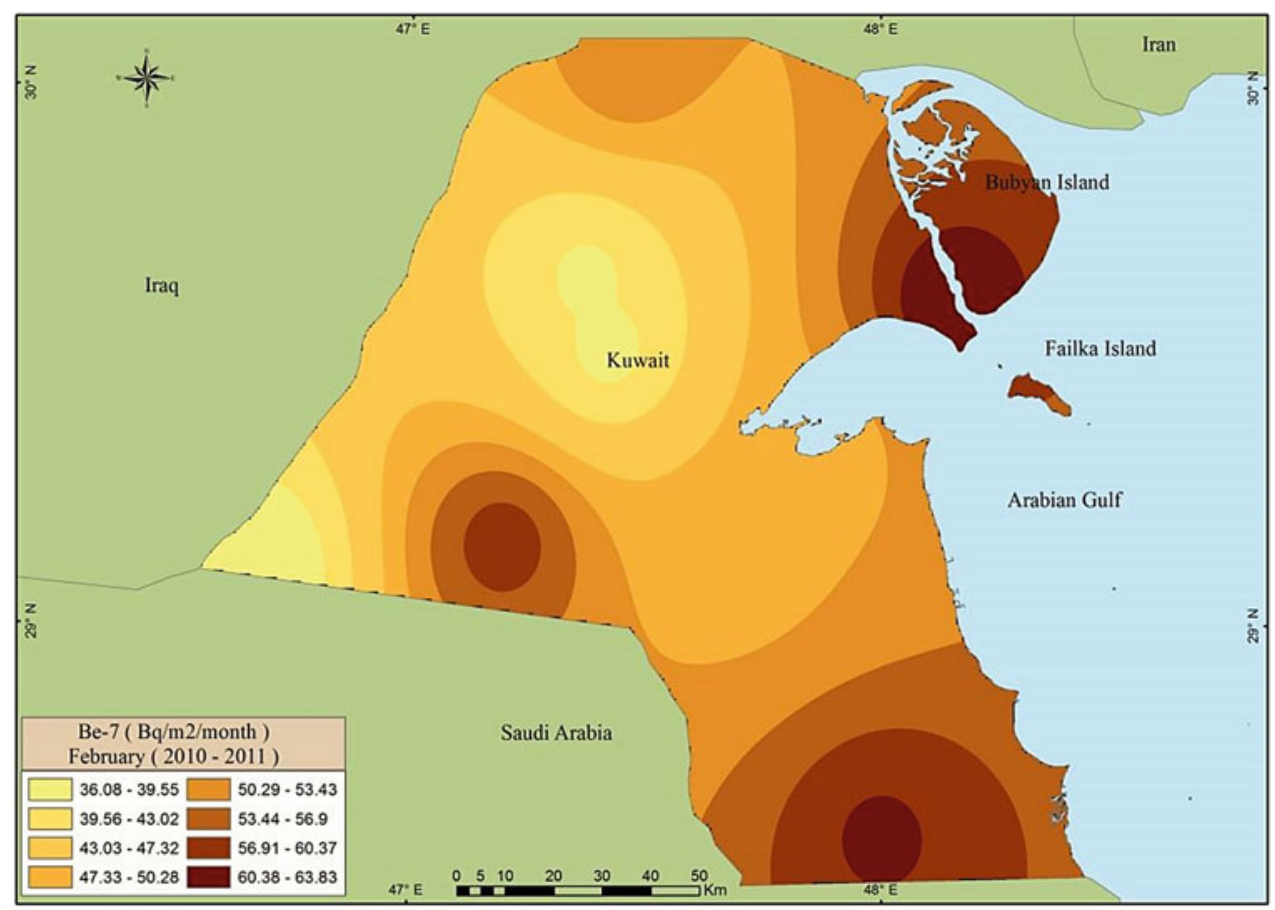


Fig. 6.6 Average deposited rates of ${ }^{7} \mathrm{Be}$ in March (2010-2011)

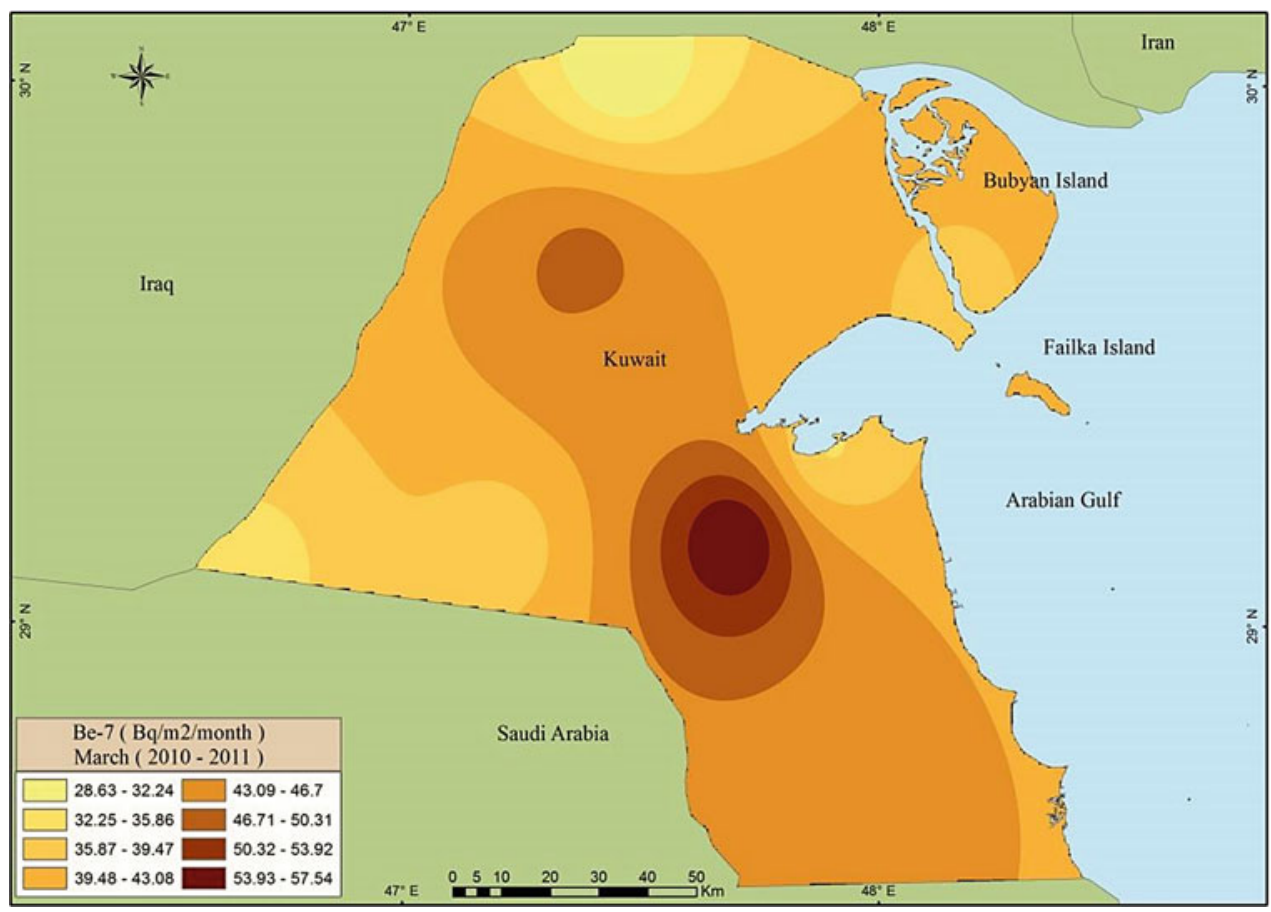

The monthly ${ }^{7} \mathrm{Be}$ deposited rates in Kuwait during March 2010-2011 reveal a range from 28.63 to $57.54 \mathrm{~Bq} \mathrm{~m}^{-2}$, with a maximum in the central region with the northern, western wind corridor, and the lowest in the northern area. The predominant wind direction for this month was northwesterly, with high speeds sometimes. However, the occurrence of dust storms was lower in February, as well as precipitation. Nevertheless, the effect of the exotic storm that hit Kuwait in March 2011 led to critical dynamic weather that could probably have decreased the ${ }^{7} \mathrm{Be}$ deposition flux (Fig. 6.6).

\begin{tabular}{l|l}
\hline $\begin{array}{l}\text { Areas with high radionuclide } \\
\text { concentration }\end{array}$ & $\begin{array}{l}\text { Areas with low radionuclide } \\
\text { concentration }\end{array}$ \\
\hline Atraf & Abdulli \\
Um Al Madafi' & Salmi \\
Liyah & Subiyah \\
Sulaybiyah & Shegaya \\
Kabd & Ratqah \\
\hline
\end{tabular}

The monthly ${ }^{7} \mathrm{Be}$ deposited rates in Kuwait during April 2010-2011 reveal the highest deposited rates, with a range from 106 to $184 \mathrm{~Bq} \mathrm{~m}{ }^{-2}$, with a maximum in the northern and central areas and the lowest in eastern central areas. The major parameter affecting this high value was the higher precipitation rate in this month (Fig. 6.7).

\begin{tabular}{l|l}
\hline $\begin{array}{l}\text { Areas with high radionuclide } \\
\text { concentration }\end{array}$ & $\begin{array}{l}\text { Areas with low radionuclide } \\
\text { concentration }\end{array}$ \\
\hline Abdulli & Salmi \\
Ratqah & Atraf \\
Roudhatain & Kabd \\
Liyah & Sulaybiyah \\
Salmiya & Wafra Farms
\end{tabular}

The monthly ${ }^{7} \mathrm{Be}$ deposited rates in Kuwait during May 2010-2011 reveal a range from 27 to $69 \mathrm{~Bq} \mathrm{~m}^{-2}$, with a maximum in the southern, eastern and northern areas and the lowest in the southern areas. The high values are attributed to the high precipitation rates this month that increased the dust washout (Fig. 6.8).

\begin{tabular}{l|l}
\hline $\begin{array}{l}\text { Areas with high radionuclide } \\
\text { concentration }\end{array}$ & $\begin{array}{l}\text { Areas with low radionuclide } \\
\text { concentration }\end{array}$ \\
\hline Salmi & Sulaybiyah \\
Shegaya & Wafra Farms \\
Dibdibah & Salmiya \\
Huwaymilyah & Khiran \\
Ubayriq & KhurFawaris \\
\hline
\end{tabular}

The monthly ${ }^{7} \mathrm{Be}$ deposited rates in Kuwait during June 2010-2011 reveal a lower rate than previous months, with a range from 4.23 to $17.32 \mathrm{~Bq} \mathrm{~m}^{-2}$. The maximum rates were in the northern and western areas, while the lowest were in 
Fig. 6.7 Average deposited rates of ${ }^{7} \mathrm{Be}$ in April (2010-2011)

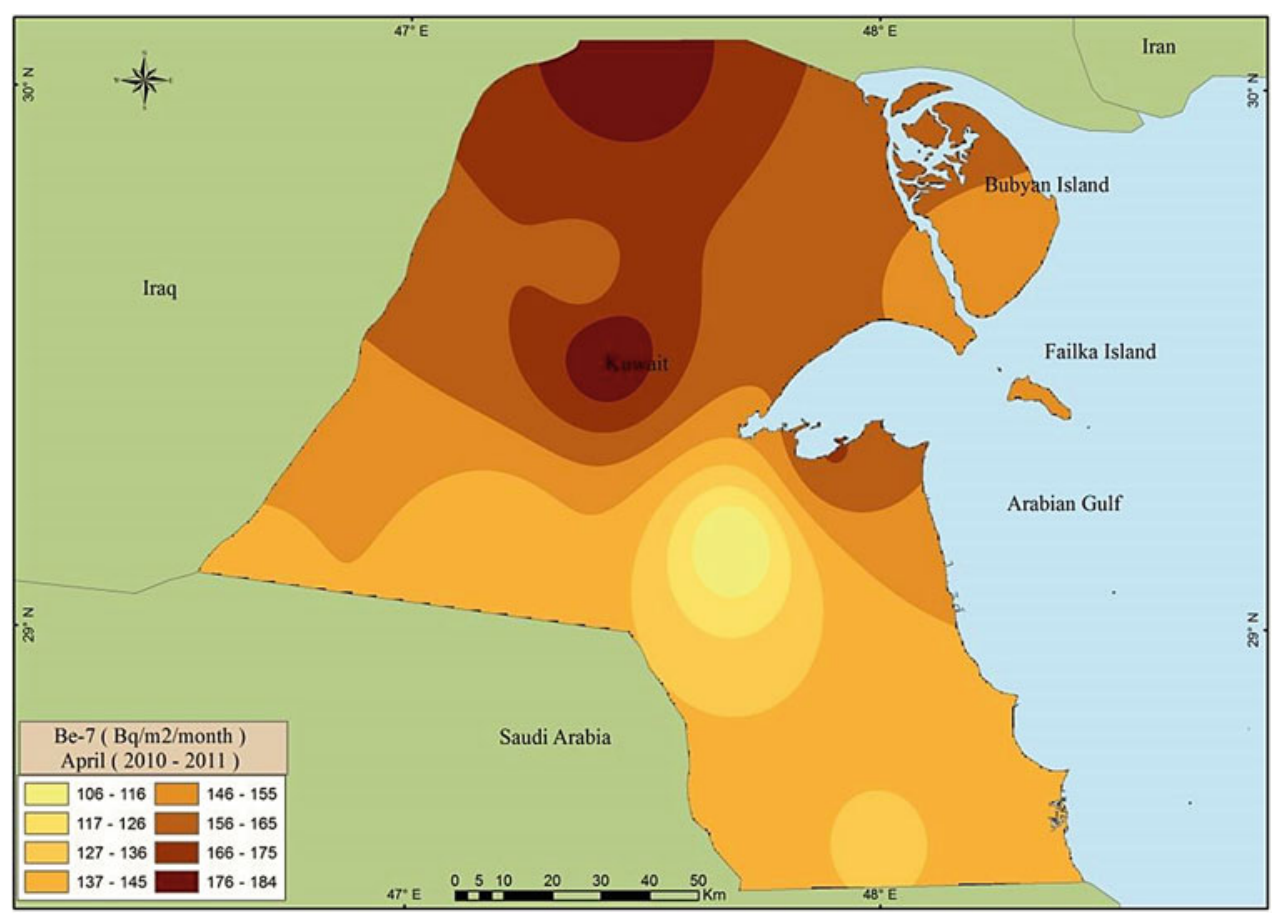

Fig. 6.8 Average deposited rates of ${ }^{7}$ Be in May (2010-2011)

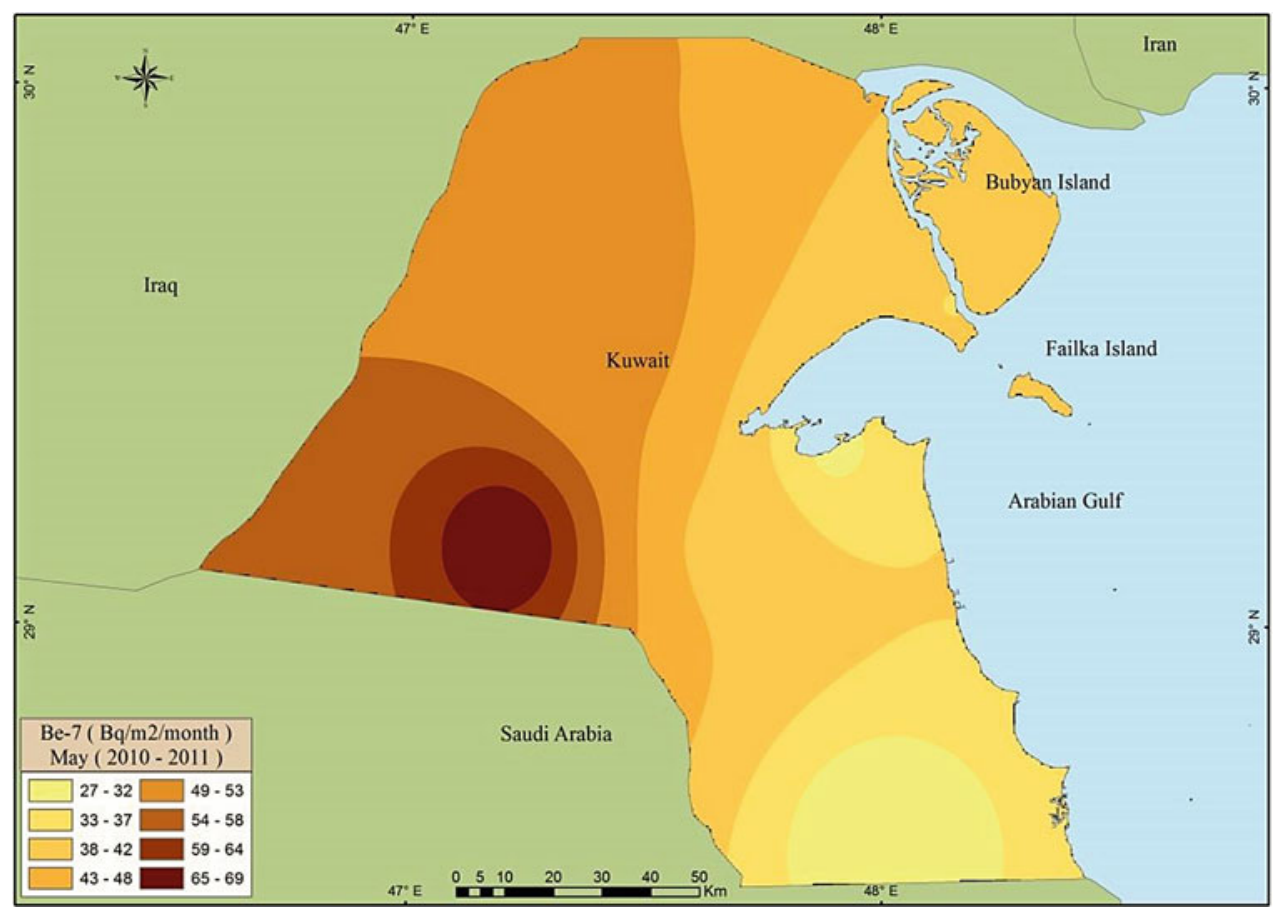


Fig. 6.9 Average deposited rates of ${ }^{7} \mathrm{Be}$ in June (2010-2011)

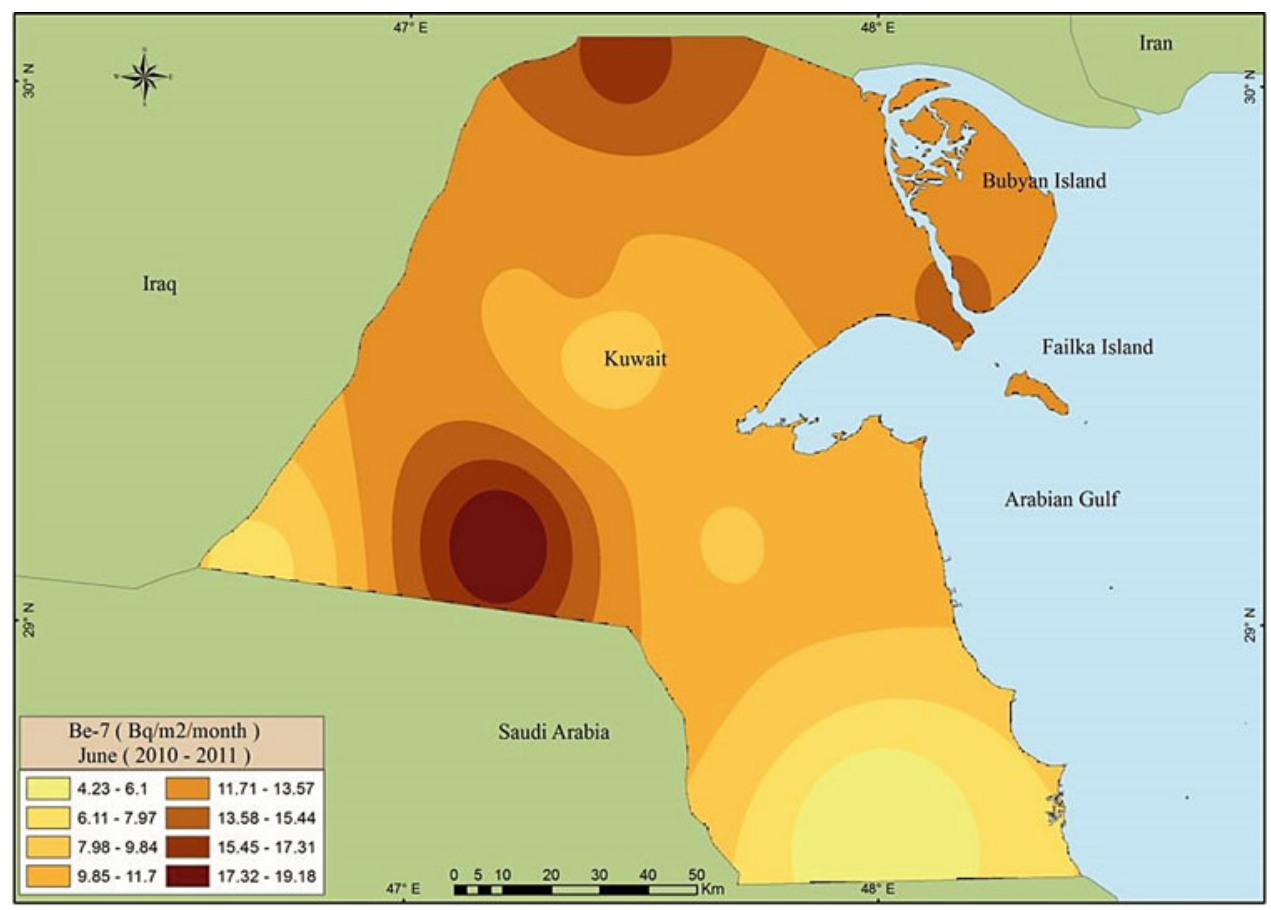

the southern and eastern areas. The predominant wind direction for this month was northwesterly, with no precipitation events (Fig. 6.9).

\begin{tabular}{l|l}
\hline $\begin{array}{l}\text { Areas with high radionuclide } \\
\text { concentration }\end{array}$ & $\begin{array}{l}\text { Areas with low radionuclide } \\
\text { concentration }\end{array}$ \\
\hline Abdulli & Liyah \\
Ratqah & Wafra Farms \\
Dibdibah & Salmi \\
Subiyah & Khiran \\
Ubayriq & KhurFawaris \\
\hline
\end{tabular}

Similar to June, the monthly ${ }^{7}$ Be deposited rates in Kuwait during July 2010-2011 reveal lower rates than previous months, with a range from 3.71 to $11.78 \mathrm{~Bq} \mathrm{~m}^{-2}$. The maximum rates were in the northern eastern areas and the lowest in the southern and northeastern areas. The predominant wind direction for this month was northwesterly, with no precipitation events to impact wind from other directions (Fig. 6.10).

\begin{tabular}{l|l}
\hline $\begin{array}{l}\text { Areas with high radionuclide } \\
\text { concentration }\end{array}$ & $\begin{array}{l}\text { Areas with low radionuclide } \\
\text { concentration }\end{array}$ \\
\hline Salmi & Liyah \\
Shegaya & Wafra Farms \\
Dibdibah & Huwaymilyah \\
Ubayriq & Khiran \\
Bubiyan Island & KhurFawaris
\end{tabular}

Similar to June and July, the monthly ${ }^{7}$ Be deposited rates in Kuwait during August 2010-2011 reveal a range from
3.66 to $29.49 \mathrm{~Bq} \mathrm{~m}^{-2}$, with a maximum in the northern areas and the lowest in the southeastern area (Fig. 6.11).

\begin{tabular}{l|l}
\hline $\begin{array}{l}\text { Areas with high radionuclide } \\
\text { concentration }\end{array}$ & $\begin{array}{l}\text { Areas with low radionuclide } \\
\text { concentration }\end{array}$ \\
\hline Abdulli & Um Madafi' \\
Ratqah & Wafra Farms \\
Roudhatain & Subiyah \\
Um Niqa & Salmi \\
Huwaymilyah & Atraf \\
\hline
\end{tabular}

Similar to the summer months, the monthly ${ }^{7} \mathrm{Be}$ deposited rates in Kuwait during September 2010-2011 reveal low rates, ranging from 2.44 to $11.6 \mathrm{~Bq} \mathrm{~m}^{-2}$, with the maximum in the northern areas and the lowest in the southern and southeastern areas (Fig. 6.12).

\begin{tabular}{l|l}
\hline $\begin{array}{l}\text { Areas with high radionuclide } \\
\text { concentration }\end{array}$ & $\begin{array}{l}\text { Areas with low radionuclide } \\
\text { concentration }\end{array}$ \\
\hline Abdulli & Salmi \\
Ratqah & Wafra Farms \\
Roudhatain & Shegaya \\
Dibdibah & Khiran \\
Huwaymilyah & KhurFawaris \\
\hline
\end{tabular}

Similar to the summer months, the monthly ${ }^{7} \mathrm{Be}$ rates deposited in Kuwait during October 2009-2010 reveal a lower rate, ranging from 5.59 to $16.09 \mathrm{~Bq} \mathrm{~m}^{-2}$, with a maximum in northeast areas, and lowest in the southern areas (Fig. 6.13). 
Fig. 6.10 Average deposited rates of ${ }^{7}$ Be for July (2010-2011)
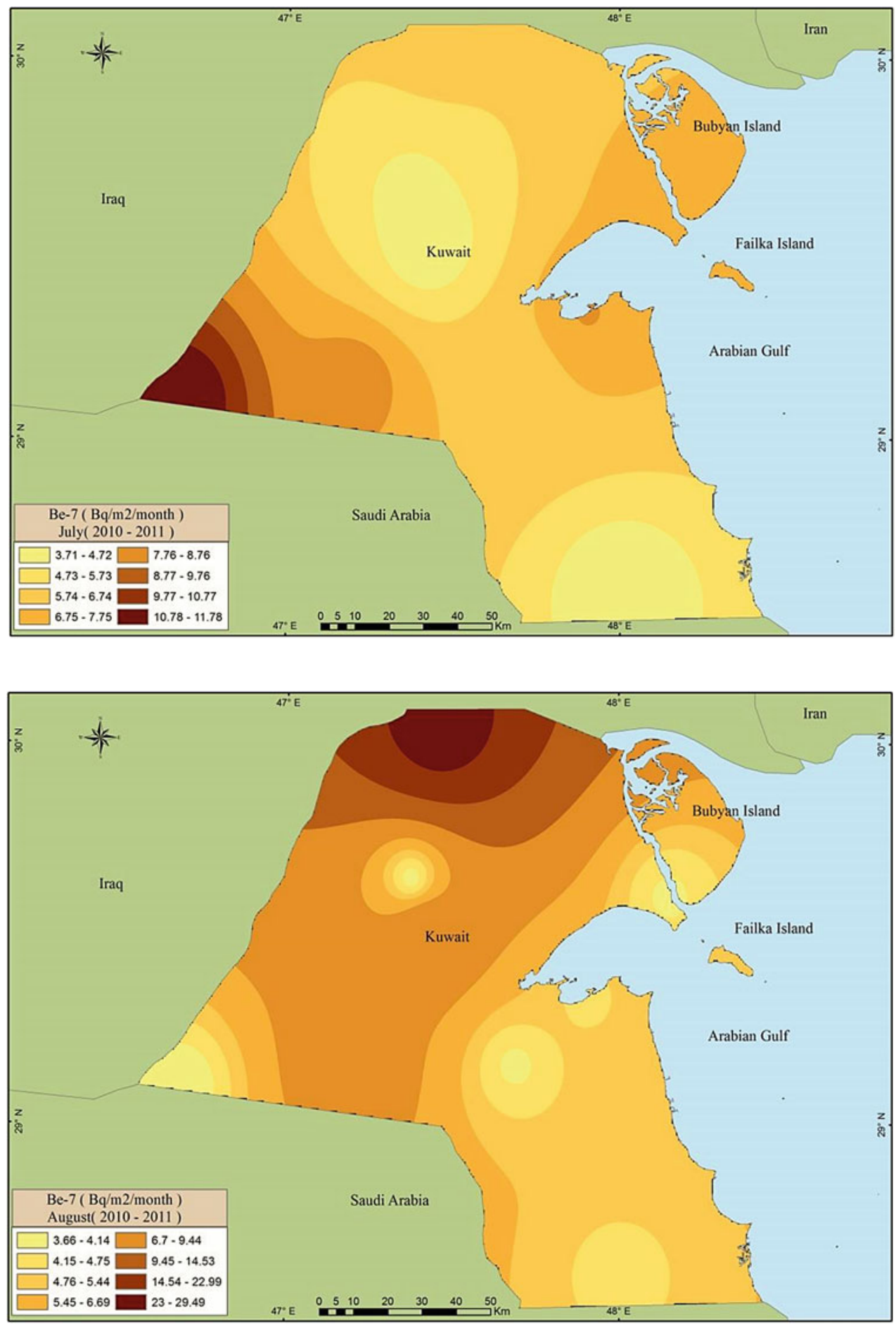

The monthly ${ }^{7} \mathrm{Be}$ deposited rates in Kuwait during

Areas with low radionuclide concentration

Liyah

Wafra Farms

Urayfijan

Khiran

KhurFawaris
Areas with high radionuclide Salmi Shegaya

Ubayriq

Dibdibah

Salmiya
November 2009-2010 reveal moderate rates that range from 4.53 to $48.04 \mathrm{~Bq} \mathrm{~m}^{-2}$, with the maximum in the central areas and the lowest in the southern, northern, and northwestern regions. The predominant wind direction was northwesterly at a minimum speed (Fig. 6.14). 
Fig. 6.12 Average percentages of ${ }^{7} \mathrm{Be}$ in September (2010-2011)

Fig. 6.13 Average deposited rates of ${ }^{7} \mathrm{Be}$ in October (20092010)
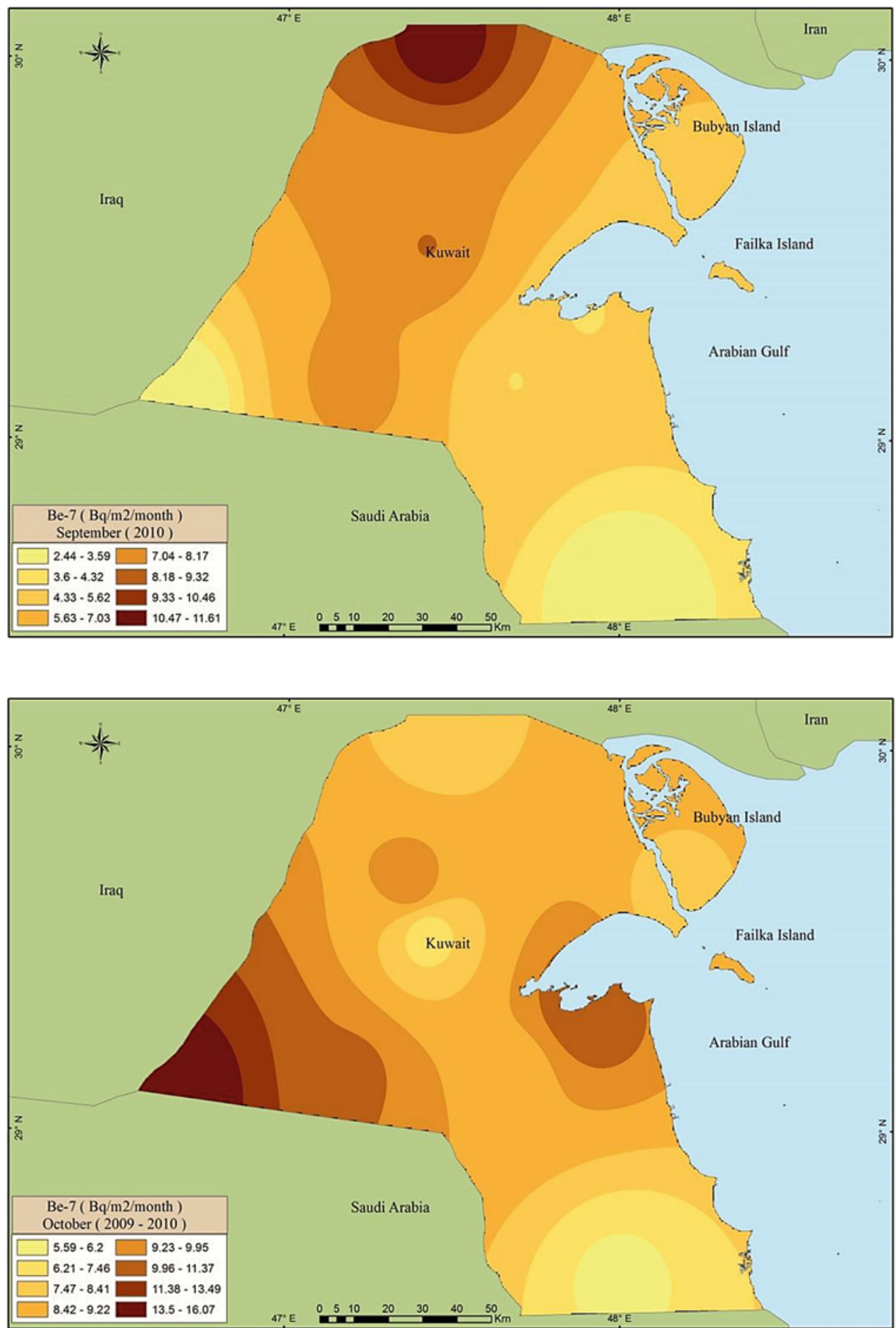

The monthly ${ }^{7} \mathrm{Be}$ rates deposited in Kuwait during Areas with low radionuclide concentration

concentration

Abdulli

Subiyah

Urayfijan

Khiran

KhurFawaris
December 2009-2010 reveal moderate rates that range from 3.69 to $46.96 \mathrm{~Bq} \mathrm{~m}^{-2}$, with the maximum in the central and central western areas and the lowest in the central southern areas. The predominant wind direction was northwesterly at high speed (Fig. 6.15). 
Fig. 6.14 Average deposited rates of ${ }^{7} \mathrm{Be}$ in November (20092010)

Fig. 6.15 Average deposited rates of ${ }^{7} \mathrm{Be}$ in December (20092010)
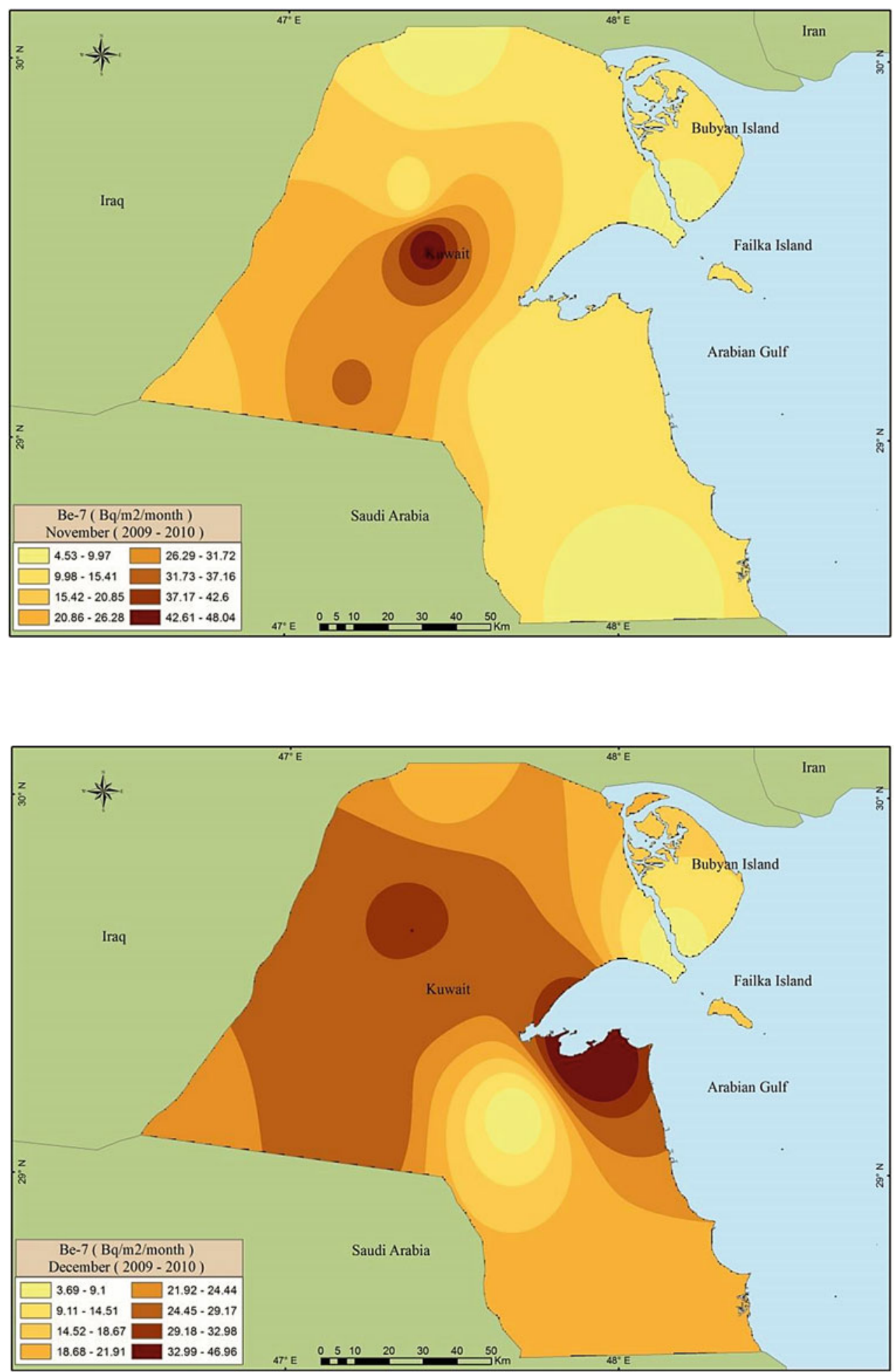


\begin{tabular}{l|l}
\hline $\begin{array}{l}\text { Areas with high radionuclide } \\
\text { concentration }\end{array}$ & $\begin{array}{l}\text { Areas with low radionuclide } \\
\text { concentration }\end{array}$ \\
\hline Gudhi & Bubiyan Island \\
Ubayriq & Subiyah \\
Dibdibah & Sulaybiyah \\
Liyah & Kabd \\
Salmiya & Atraf \\
\hline
\end{tabular}

\section{Annual Deposited Rates of ${ }^{137}$ Cs}

The average annual ${ }^{137} \mathrm{Cs}$ rates deposited in Kuwait from October 2009 to August 2011 varied from 0.2 to $4.18 \mathrm{~Bq} \mathrm{~m}^{-2}$, with an average of $4.76 \mathrm{~Bq} \mathrm{~m}^{-2}$. The maximum rates were in southwestern areas. The ${ }^{137} \mathrm{Cs}$ rates deposited gradually decreased from the interior to the coastal areas, where they reached the minimum value. The predominant annual wind direction was northwesterly (Fig. 6.16).

\begin{tabular}{l|l}
\hline $\begin{array}{l}\text { Areas with high radionuclide } \\
\text { concentration }\end{array}$ & $\begin{array}{l}\text { Areas with low radionuclide } \\
\text { concentration }\end{array}$ \\
\hline Salmi & Ratqa \\
Shegaya & Sulaybiyah \\
Ubayriq & Bubiyan Island \\
Dibdibah & Subiyah \\
Um Qudayr & Failaka Island
\end{tabular}

\section{Monthly Deposited Rates of ${ }^{137}$ Cs}

The monthly ${ }^{137} \mathrm{Cs}$ rates deposited in Kuwait during January 2010-2011 reveal a range from 0.1 to $0.39 \mathrm{~Bq} \mathrm{~m}^{-2}$, with the maximum in central and southwestern areas and the lowest in southern areas of the Wafra Farms. The predominant wind direction for this month was northwesterly, with high wind speed sometimes (Fig. 6.17).

\begin{tabular}{l|l}
\hline $\begin{array}{l}\text { Areas with high radionuclide } \\
\text { concentration }\end{array}$ & $\begin{array}{l}\text { Areas with low radionuclide } \\
\text { concentration }\end{array}$ \\
\hline Huwaymilyah & Salmi \\
Ubayriq & Subiyah \\
Dibdibah & Sulaybiyah \\
Um Al Madafi' & Khiran \\
Ratqah & KhurFawaris \\
\hline
\end{tabular}

The monthly ${ }^{137} \mathrm{Cs}$ deposited rates in Kuwait during February 2010-2011 varied from 0.21 to $0.54 \mathrm{~Bq} \mathrm{~m}^{-2}$, with two high deposition rate spots. This possibly happened because of the effect of the dust storms in this month. The predominant wind direction for this month was northwesterly, and the precipitation rates were low (Fig. 6.18).

\begin{tabular}{l|l}
\hline $\begin{array}{l}\text { Areas with high radionuclide } \\
\text { concentration }\end{array}$ & $\begin{array}{l}\text { Areas with low radionuclide } \\
\text { concentration }\end{array}$ \\
\hline $\begin{array}{l}\text { Salmi } \\
\text { Shegaya }\end{array}$ & $\begin{array}{l}\text { Ratqah } \\
\text { Liyah }\end{array}$
\end{tabular}

(continued)
Fig. 6.16 Average deposited rates of ${ }^{137} \mathrm{Cs}$ in (Oct 2009-Aug 2011)

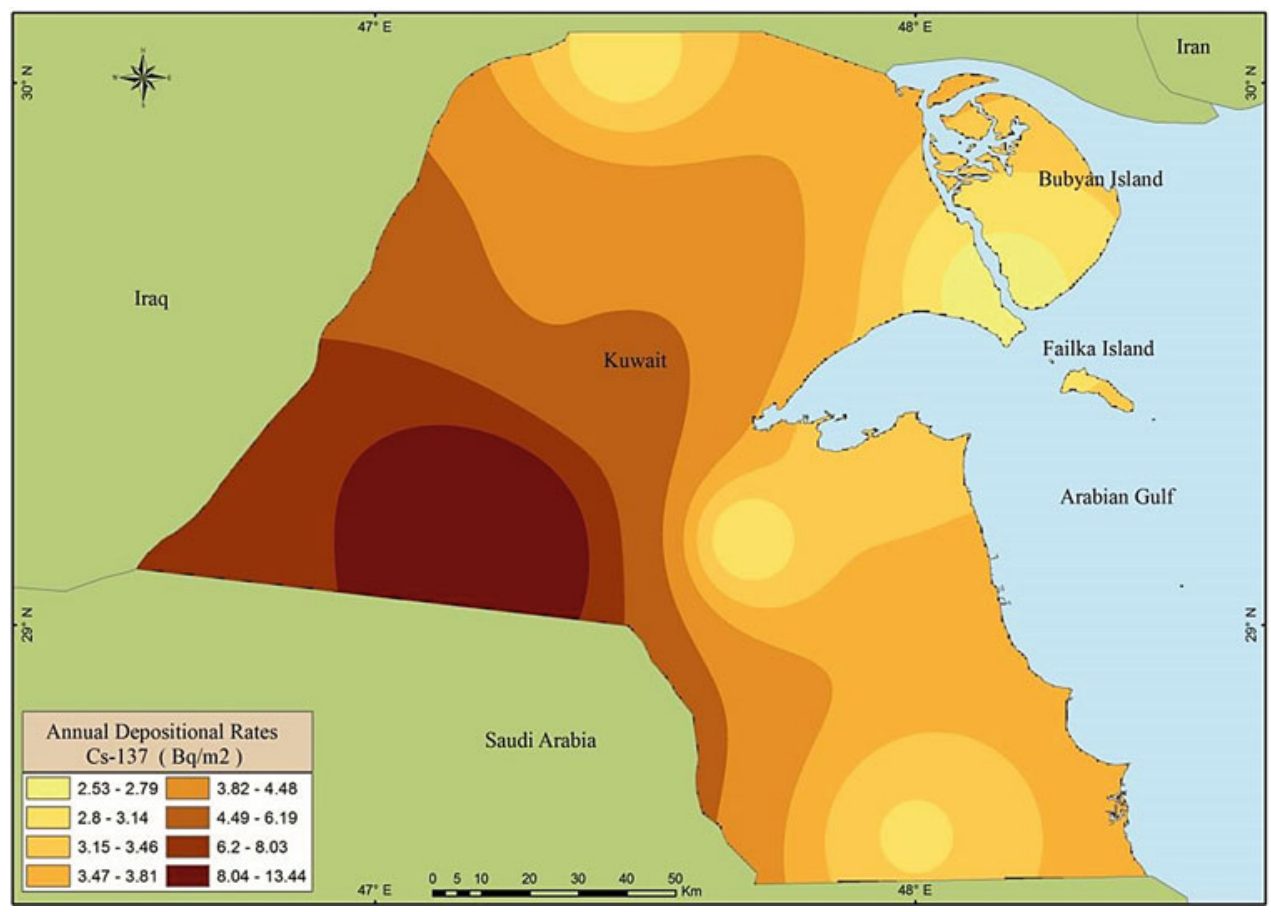


Fig. 6.17 Average deposited rates of ${ }^{137}$ Cs in January (20102011)

Fig. 6.18 Average deposited rates of ${ }^{137} \mathrm{Cs}$ in February (20102011)
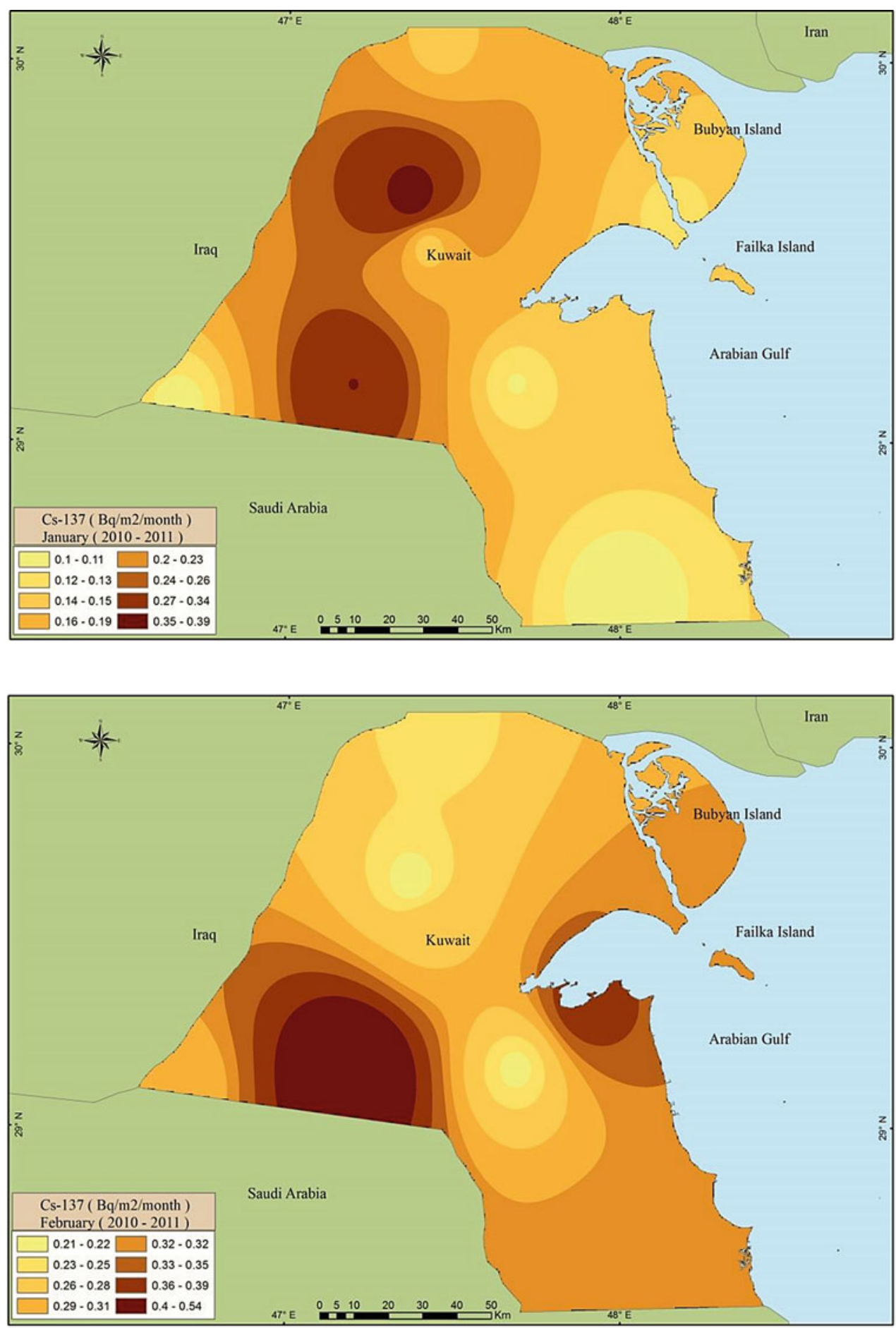
Fig. 6.19 Average deposited rates of ${ }^{137} \mathrm{Cs}$ in March (20102011)

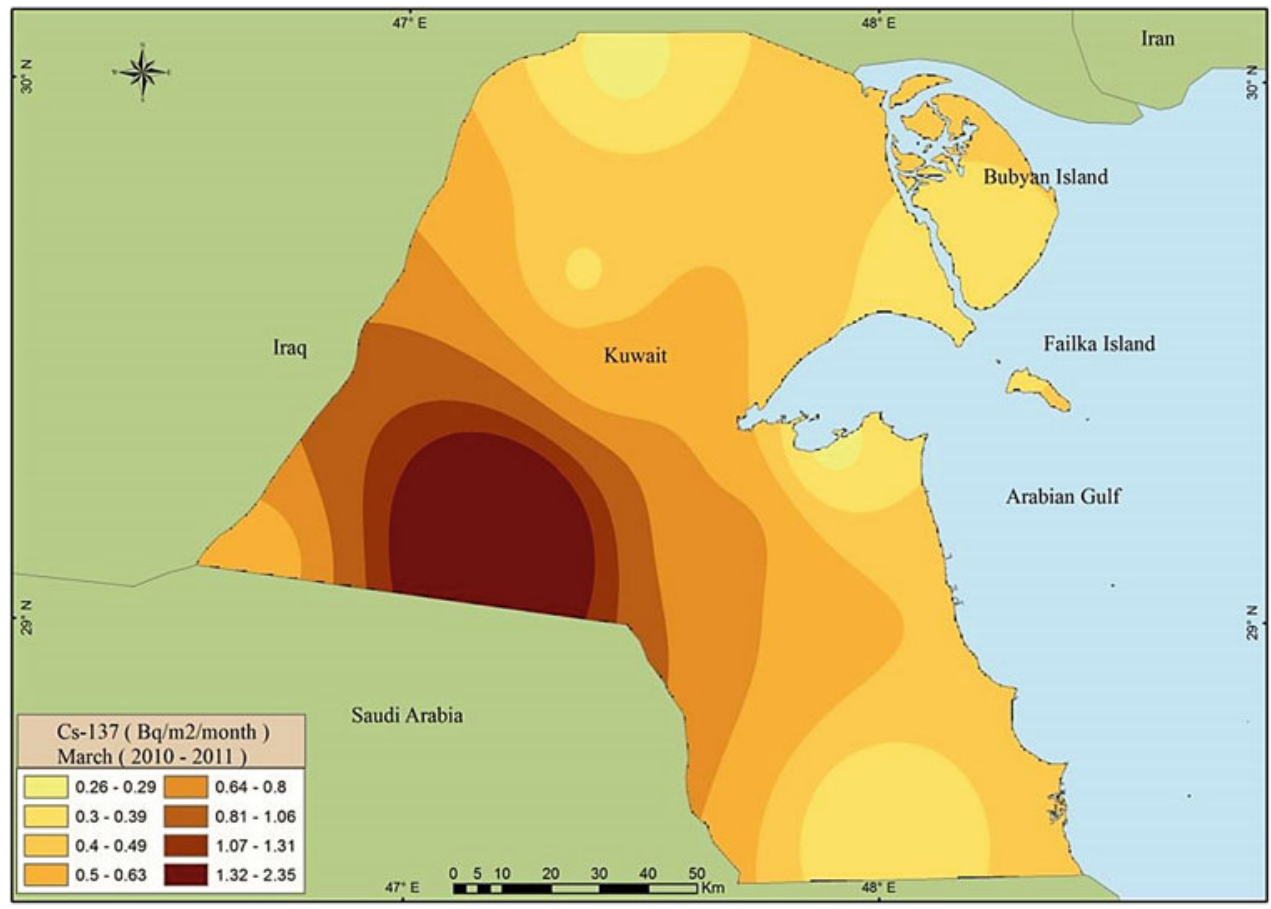

Areas with low radionuclide concentration

Roudhatain
Sulaybiyah
Atraf

Atraf

The monthly ${ }^{137} \mathrm{Cs}$ rates deposited in Kuwait during March 2010-2011 reveal a high range that varied from 0.26 to $2.35 \mathrm{~Bq} \mathrm{~m}^{2}$, with the maximum in the southwestern area and the lowest in the northern and southern regions. The predominant wind direction for this month was northwesterly, with high speed sometimes. However, the highest deposition flux was reported in this month due to the effect of the exotic storm that hit Kuwait, in addition to the high precipitation recorded (Fig. 6.19).

\begin{tabular}{l|l}
\hline $\begin{array}{l}\text { Areas with high radionuclide } \\
\text { concentration }\end{array}$ & $\begin{array}{l}\text { Areas with low radionuclide } \\
\text { concentration }\end{array}$ \\
\hline Kabd & Ratqa \\
Shegaya & Subiyah \\
Ubayriq & Bubiyan Island \\
Dibdibah & Salmiya \\
Um Qudayr & Wafra Farms \\
\hline
\end{tabular}

The monthly ${ }^{137} \mathrm{Cs}$ rates deposited in Kuwait during April 2010-2011 ranged from 0.67 to $1.4 \mathrm{~Bq} \mathrm{~m}^{-2}$, which is considered high, but it is less than March due to lower precipitation. The predominant wind direction was northwesterly, with a high wind speed of northeasterly, easterly, and southeasterly direction (Fig. 6.20).

\begin{tabular}{l|l}
\hline $\begin{array}{l}\text { Areas with high radionuclide } \\
\text { concentration }\end{array}$ & $\begin{array}{l}\text { Areas with low radionuclide } \\
\text { concentration }\end{array}$ \\
\hline Shegaya & $\begin{array}{l}\text { Subiyah } \\
\text { Ubayriq }\end{array}$ \\
Bubiyan Island \\
Subdibah & Sulaybiyah \\
Huwaymilyah & Kabd \\
Um Al Madafi & Jal Al Zur \\
\hline
\end{tabular}

The monthly ${ }^{137} \mathrm{Cs}$ rates deposited in Kuwait during May 2010-2011 ranged from 0.22 to $2.23 \mathrm{~Bq} \mathrm{~m}^{-2}$, with the maximum in the southeastern and central regions. The lowest deposition fluxes were in the southern and eastern areas. However, the slightly high deposition flux in this month was due to the effect of the exotic storm that hit Kuwait on March 25, 2011 (Fig. 6.21).

\begin{tabular}{l|l}
\hline $\begin{array}{l}\text { Areas with high radionuclide } \\
\text { concentration }\end{array}$ & $\begin{array}{l}\text { Areas with low radionuclide } \\
\text { concentration }\end{array}$ \\
\hline Shegaya & Subiyah \\
Ubayriq & Bubiyan Island \\
Dibdibah & Salmiya \\
Huwaymilyah & Wafra Farms \\
Liyah & Shuaiba
\end{tabular}

The monthly ${ }^{137} \mathrm{Cs}$ deposited rates in Kuwait during June 2010-2011 display similar rates to previous months, but with lower minimum rates, the range varied from 0.06 to $1.3 \mathrm{~Bq} \mathrm{~m}^{-2}$. The maximum rates were in southeast areas, and the lowest was in central areas. The predominant wind direction for this month was northwesterly, with no precipitation events (Fig. 6.22). 
Fig. 6.20 Average deposited rates of ${ }^{137}$ Cs in April (2010 2011)

Fig. 6.21 Average deposited rates of ${ }^{137}$ Cs in May (20102011)
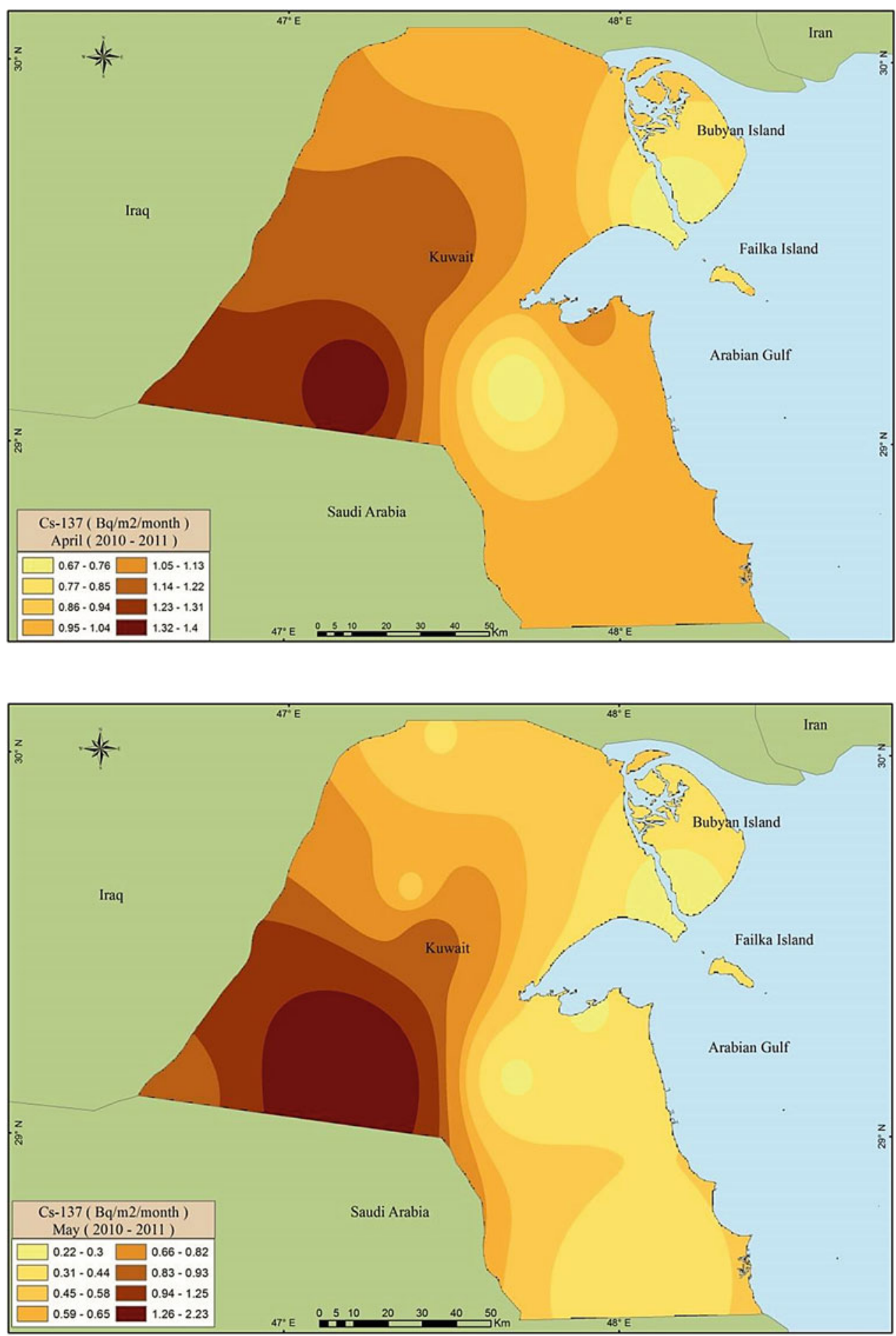

Areas with low radionuclide concentration

concentration

Kabd

Shegaya

Ubayriq

Dibdibah

Um Qudayr

Abdulli

Atraf

Mutla

Liyah

Wafra Farms
The monthly ${ }^{137} \mathrm{Cs}$ rates deposited in Kuwait during July 2010-2011 showed similar rates to the other summer months. The range of deposition flux varied between 0.09 and $1.39 \mathrm{~Bq}$ $\mathrm{m}^{-2}$. The maximum rates were in northeastern areas and the lowest in southern and northeastern areas. The predominant wind direction for this month was northwesterly, with no precipitation events that impact wind from other directions (Fig. 6.23). 
Fig. 6.22 Average deposited rates of ${ }^{137} \mathrm{Cs}$ in June (20102011)

Fig. 6.23 Average deposited rates of ${ }^{137}$ Cs in July (20102011)
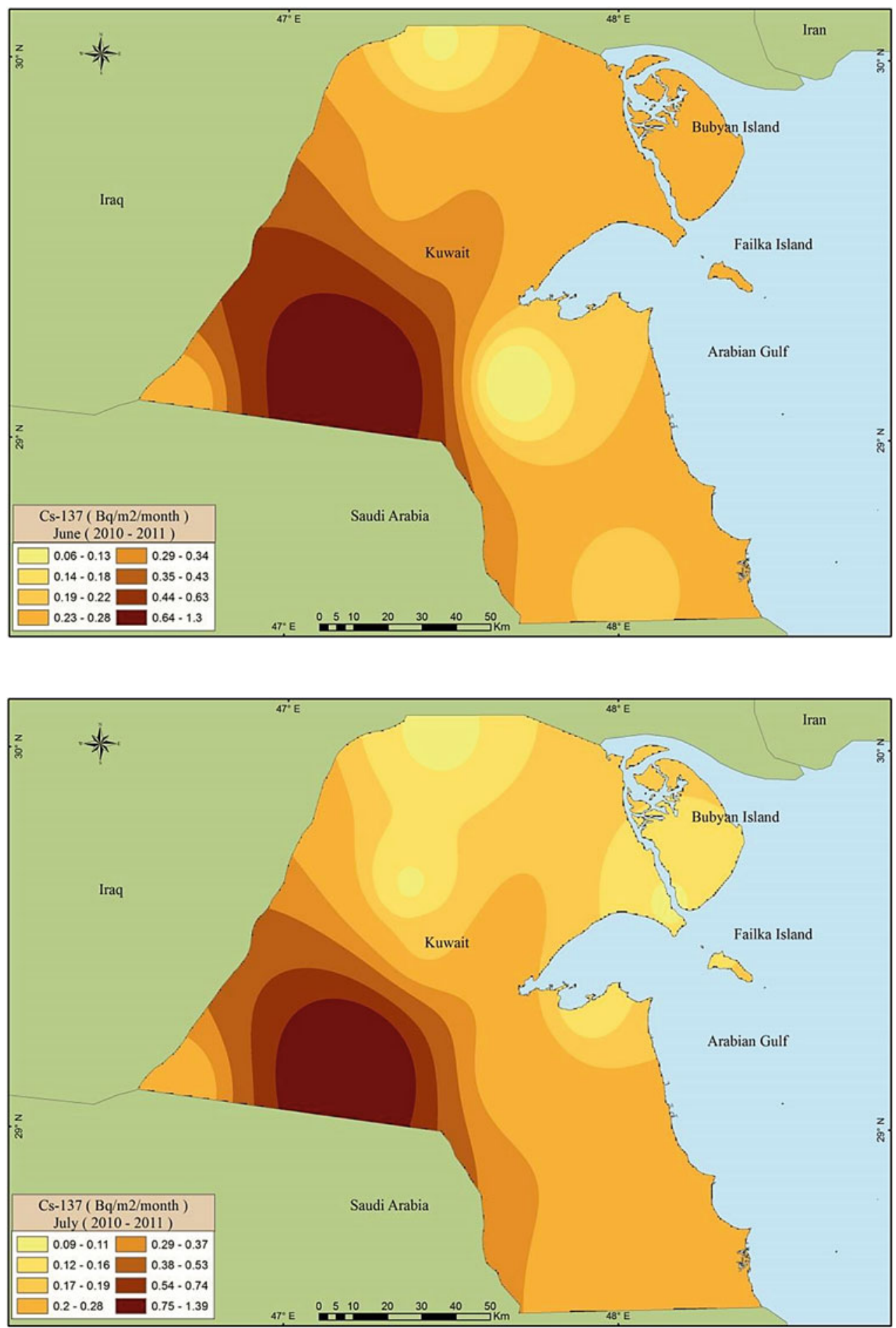
Fig. 6.24 Average deposited rates of ${ }^{137} \mathrm{Cs}$ in August (20102011)

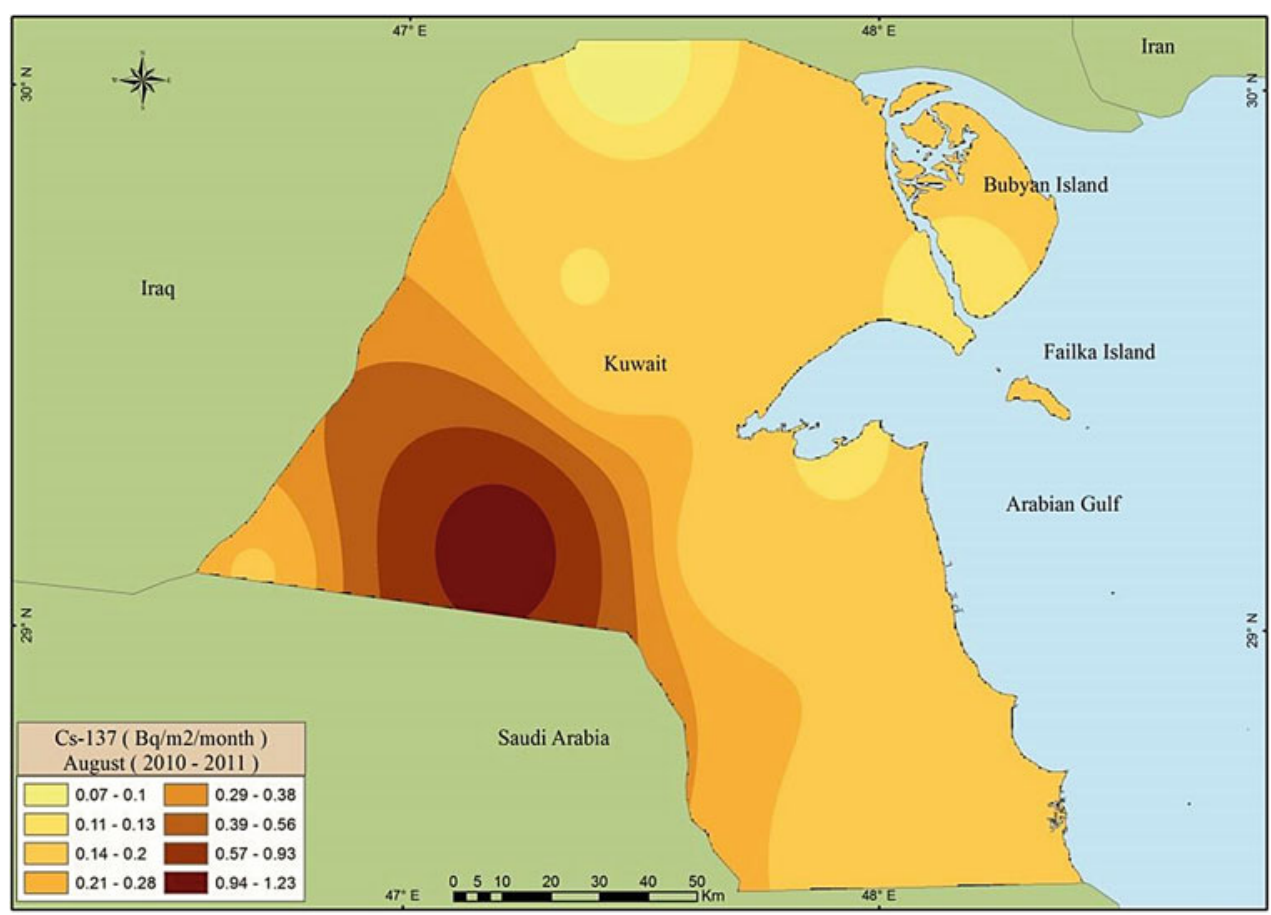

Areas with low radionuclide concentration

\section{concentration}

Areas with high radionuclide

\section{Shegaya}

Ubayriq

Dibdibah

Um Qudayr

Huwaymilyah

Abdulli
Ratqah
Um Al Madafi'
Salmiya
Bubiyan Island

The monthly ${ }^{137} \mathrm{Cs}$ rates deposited in Kuwait during August 2010-2011 showed similar rates in June and July, with a range that varied from 0.07 to $1.23 \mathrm{~Bq} \mathrm{~m}^{-2}$, with the maximum in the southwestern areas and the lowest in the southern areas (Fig. 6.24).

\begin{tabular}{l|l}
\hline $\begin{array}{l}\text { Areas with high radionuclide } \\
\text { concentration }\end{array}$ & $\begin{array}{l}\text { Areas with low radionuclide } \\
\text { concentration }\end{array}$ \\
\hline Shegaya & Abdulli \\
Ubayriq & Ratqah \\
Dibdibah & Um Al Madaf' \\
Um Qudayr & Salmiya \\
Huwaymilyah & Bubiyan Island \\
\hline
\end{tabular}

Similar to the summer months, the monthly ${ }^{137} \mathrm{Cs}$ rates deposited in Kuwait during September 2010-2011 ranged from 0.05 to $0.87 \mathrm{~Bq} \mathrm{~m}^{-2}$, with the maximum in southwestern areas and the lowest in northern and central areas. The predominant wind direction in this month was northwesterly, with no contribution from other directions (Fig. 6.25).

\begin{tabular}{l|l}
\hline $\begin{array}{l}\text { Areas with high radionuclide } \\
\text { concentration }\end{array}$ & $\begin{array}{l}\text { Areas with low radionuclide } \\
\text { concentration }\end{array}$ \\
\hline Huwaymilyah & Abdulli \\
Ubayriq & Ratqah \\
Dibdibah & Um Al Madafi \\
Um Qudayr & Sulaybiyah \\
Liyah & Wafra Farms
\end{tabular}

Similar to the summer months, the monthly ${ }^{137} \mathrm{Cs}$ rates deposited in Kuwait during October 2010-2011 ranged from 0.07 to $0.72 \mathrm{~Bq} \mathrm{~m}^{-2}$, with the maximum in southwestern areas and the lowest in northern and central eastern areas. The predominant wind direction in this month was northwesterly, with no contribution from other directions (Fig. 6.26).

\begin{tabular}{l|l}
\hline $\begin{array}{l}\text { Areas with high radionuclide } \\
\text { concentration }\end{array}$ & $\begin{array}{l}\text { Areas with low radionuclide } \\
\text { concentration }\end{array}$ \\
\hline $\begin{array}{l}\text { Huwaymilyah } \\
\text { Ubayriq }\end{array}$ & Um Al Madafi \\
Dibdibah & Sulaybiyah \\
Um Qudayr & Wafra Farms \\
Salmi & Salmiya \\
& Bubiyan Island
\end{tabular}

The monthly ${ }^{137} \mathrm{Cs}$ rates deposited in Kuwait during November 2009-2010 showed moderate rates ranging from 0.06 to $1.54 \mathrm{~Bq} \mathrm{~m}^{-2}$, with the maximum in the central and eastern areas and the lowest in southern areas. The predominant wind direction was northwesterly with minimum speed (Fig. 6.27). 
Fig. 6.25 Average deposited rates of ${ }^{137} \mathrm{Cs}$ in September (2010)

Fig. 6.26 Average deposited rates of ${ }^{137} \mathrm{Cs}$ in October (20092010)
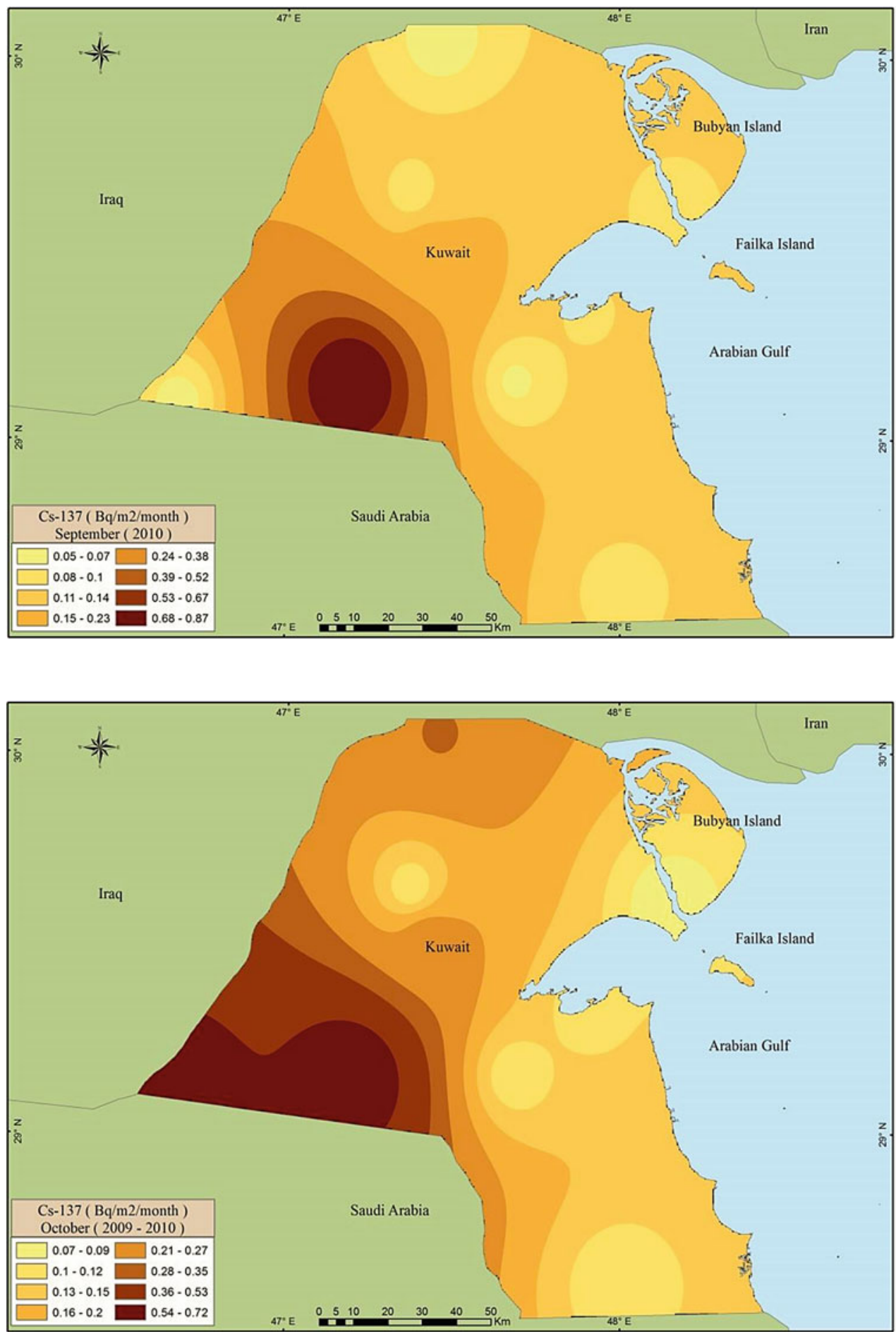

Areas with low radionuclide

The monthly ${ }^{137} \mathrm{Cs}$ rates deposited in Kuwait during December 2009-2010 reveals lower rates than during summer. The deposition rates varied from 0.04 to $0.17 \mathrm{~Bq} \mathrm{~m}^{-2}$, with the maximum value observed along the transect from the central to southwestern areas. The predominant wind direction was northwesterly, with high speed at times (Fig. 6.28). concentration

Areas with high radionuclide concentration

Huwaymilyah

Ubayriq

Dibdibah

Shegaya

Salmi

Ratqah

Sulaybiyah

Wafra Farms

Salmiya

Bubiyan Island 
Fig. 6.27 Average deposited rates of ${ }^{137} \mathrm{Cs}$ in November (2009-2010)

Fig. 6.28 Average deposited rates of ${ }^{137} \mathrm{Cs}$ in December (2009-2010)
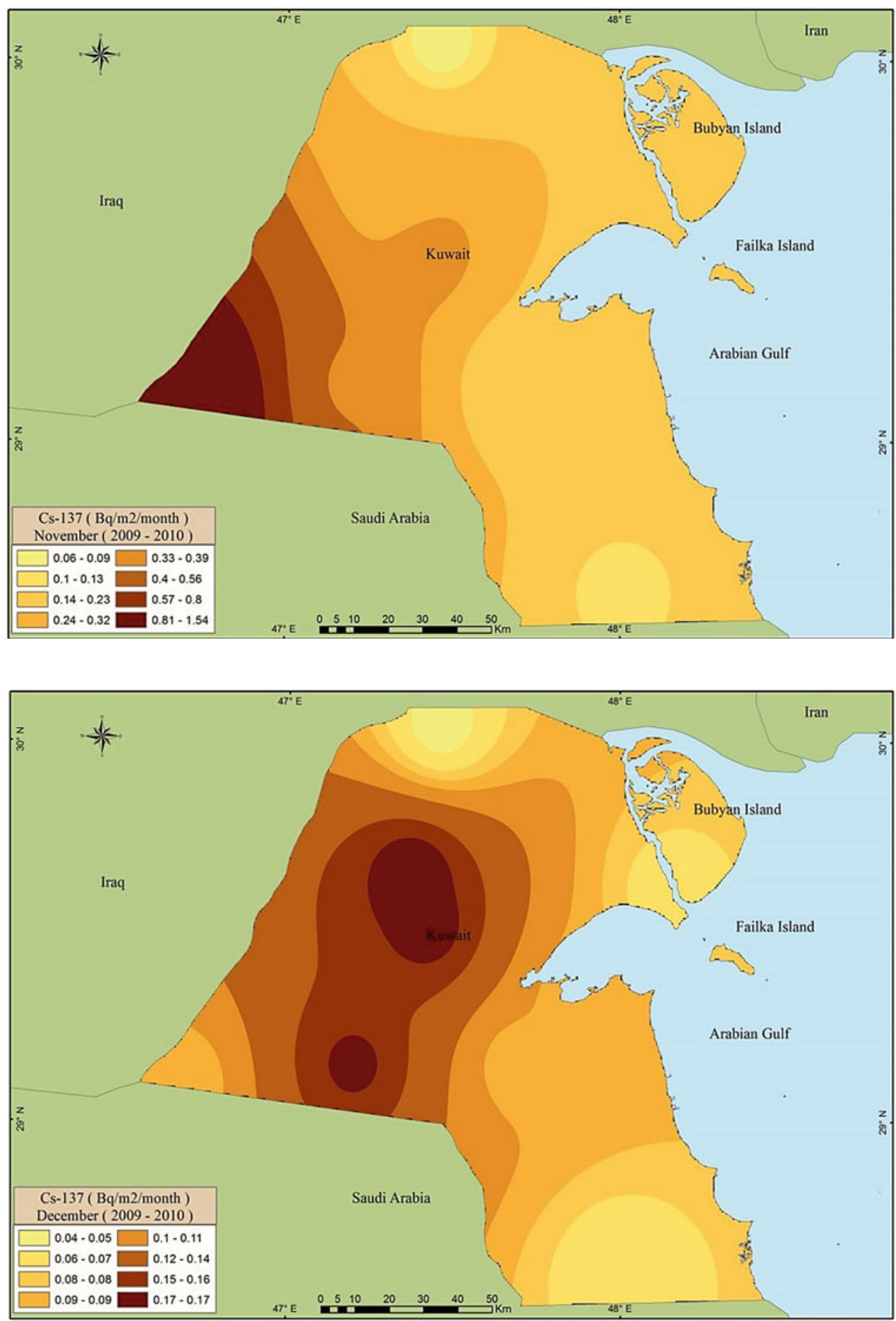

Areas with low radionuclide concentration

concentration

Abdulli

Subiyah

KhurFawaris

Khiran

Wafra Farms

\section{Annual Deposited Rates of ${ }^{40} \mathrm{~K}$}

The average annual ${ }^{40} \mathrm{~K}$ deposited rates in Kuwait from October 2009 to August 2011 varied from 74 to $557 \mathrm{~Bq}$ $\mathrm{m}^{-2}$, with an average of about $160 \mathrm{~Bq} \mathrm{~m}^{-2}$. The maximum rates were found in the southwestern areas. The ${ }^{40} \mathrm{~K}$ 
Fig. 6.29 Average deposited rates of ${ }^{40} \mathrm{~K}$ in (Oct 2009-Aug 2011)

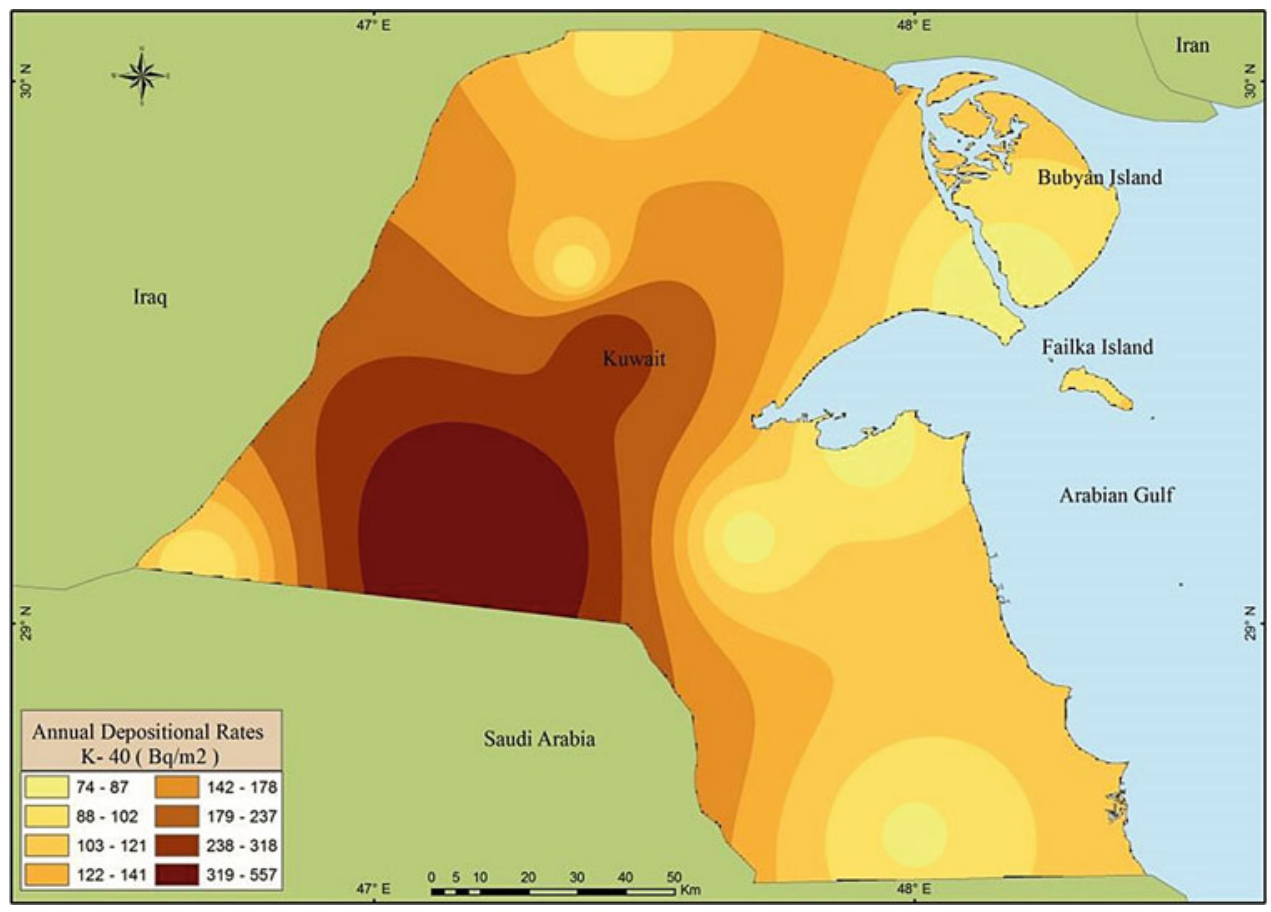

deposited rates gradually decreased from the interior to the coastal areas, where it reached the minimum. The predominant annual wind direction was northwesterly (Fig. 6.29).

\begin{tabular}{l|l}
\hline $\begin{array}{l}\text { Areas with high radionuclide } \\
\text { concentration }\end{array}$ & $\begin{array}{l}\text { Areas with low radionuclide } \\
\text { concentration }\end{array}$ \\
\hline Huwaymilyah & Abdulli \\
Ubayriq & Subiyah \\
Dibdibah & Atraf \\
Um Eish & Salmiya \\
Liyah & Wafra Farms
\end{tabular}

\section{Monthly Deposited Rates of ${ }^{40} \mathrm{~K}$}

The monthly ${ }^{40} \mathrm{~K}$ deposited rates in Kuwait during January 2010-2011 ranged from 1.14 to $15.62 \mathrm{~Bq} \mathrm{~m}^{-2}$, with the maximum in southeastern and western areas, and the lowest was in the central areas. The predominant wind direction for this month was northwesterly, with high wind speed at times (Fig. 6.30).

\begin{tabular}{l|l}
\hline $\begin{array}{l}\text { Areas with high radionuclide } \\
\text { concentration }\end{array}$ & $\begin{array}{l}\text { Areas with low radionuclide } \\
\text { concentration }\end{array}$ \\
\hline Huwaymilyah & Abdulli \\
Ubayriq & Subiyah \\
Dibdibah & Liyah \\
Salmi & Salmiya \\
Wafra Farms & Sulaybiyah \\
\hline
\end{tabular}

The monthly ${ }^{40} \mathrm{~K}$ rates deposited in Kuwait during February 2010-2011 varied from 3.13 to $23.0 \mathrm{~Bq} \mathrm{~m}^{-2}$, with a high deposition rate noted in southeastern areas. This possibly happened because of dust storms that occurred in this month. The predominant wind direction for this month was northwesterly, and the precipitation rates were low (Fig. 6.31).

\begin{tabular}{l|l}
\hline $\begin{array}{l}\text { Areas with high radionuclide } \\
\text { concentration }\end{array}$ & $\begin{array}{l}\text { Areas with low radionuclide } \\
\text { concentration }\end{array}$ \\
\hline $\begin{array}{l}\text { Huwaymilyah } \\
\text { Ubayriq }\end{array}$ & Abdulli \\
Dibdibah & Subiyah \\
Liyah & Um Al Madaf' \\
Um Qudayr & Salmiya \\
\hline
\end{tabular}

The monthly ${ }^{40} \mathrm{~K}$ rates deposited in Kuwait during March 2010-2011 had a high range that varied from 5.19 to 96.27 $\mathrm{Bq} \mathrm{m}^{-2}$, with the maximum in the southwestern area and the lowest in the northern and southern areas. The predominant wind direction for this month was northwesterly, with high speed registered at times. However, the highest deposition flux was reported in this month because of the effect of the exotic storm that hit Kuwait, in addition to high precipitation (Fig. 6.32).

\begin{tabular}{l|l}
\hline $\begin{array}{l}\text { Areas with high radionuclide } \\
\text { concentration }\end{array}$ & $\begin{array}{l}\text { Areas with low radionuclide } \\
\text { concentration }\end{array}$ \\
\hline Huwaymilyah & Abdulli \\
Ubayriq & Subiyah \\
Dibdibah & Wafra Farms \\
Liyah & Salmiya \\
Um Qudayr & Bubiyan Island
\end{tabular}


Fig. 6.30 Average deposited rates of ${ }^{40} \mathrm{~K}$ in January (20102011)

Fig. 6.31 Average deposited rates of ${ }^{40} \mathrm{~K}$ in February (2010 2011)
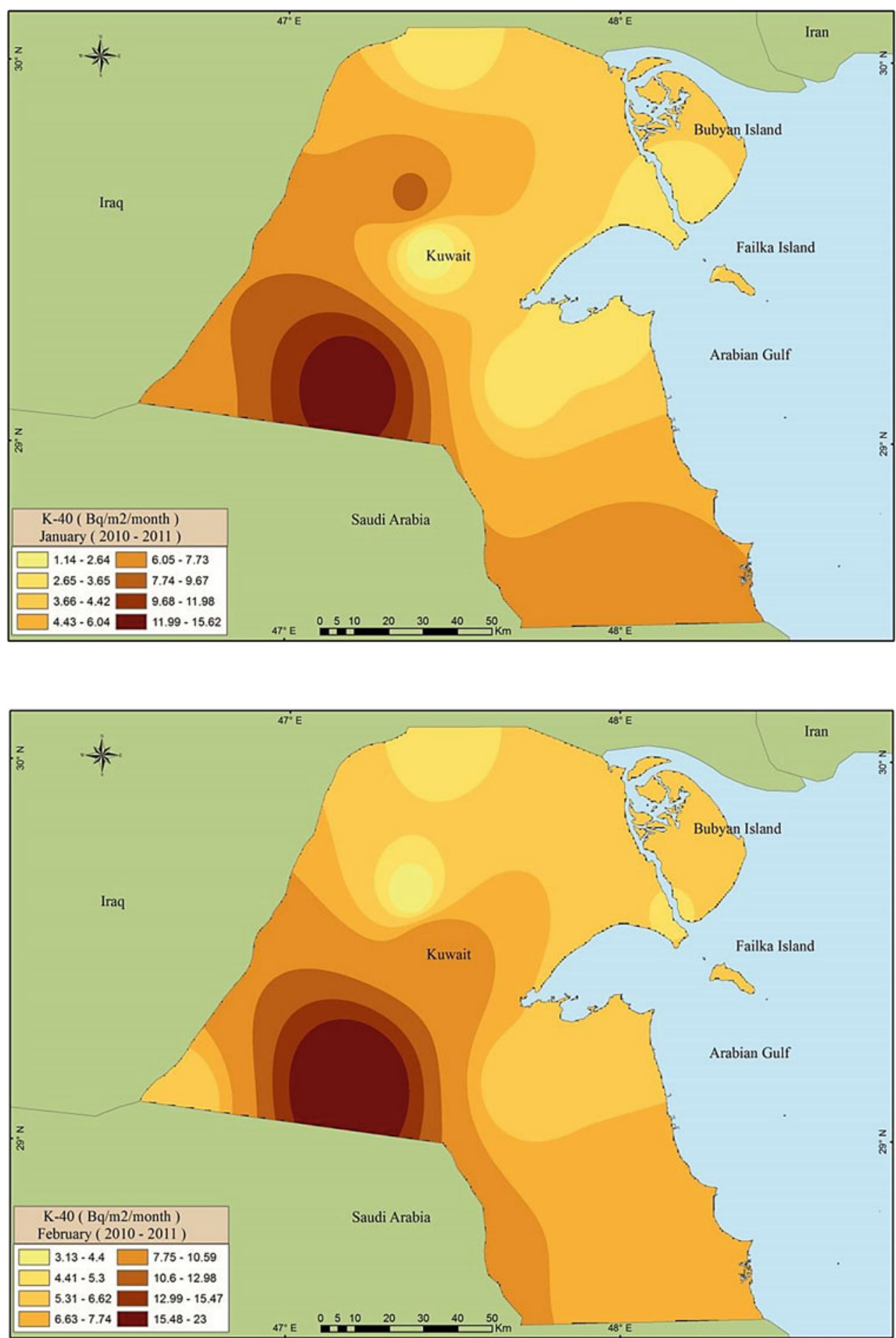

The monthly ${ }^{40} \mathrm{~K}$ rates deposited in Kuwait during April 2010-2011 ranged from 12.88 to $69.77 \mathrm{~Bq} \mathrm{~m}^{-2}$, which is considered high but is lower than the rates in March due to lower precipitation rates. A spot with high deposition rates was found in the central areas. The predominant wind direction was northwesterly, with a high wind speed of northeastern, eastern, and southeastern wind contribution. The critical dynamic weather due to Koss and Sarrayat that occurred in spring contributed toward the high deposition rates (Fig. 6.33). 
Fig. 6.32 Average deposited rates of ${ }^{40} \mathrm{~K}$ in March (2010 2011)

Fig. 6.33 Average deposited rates of ${ }^{40} \mathrm{~K}$ in April (2010-2011) concentration

Huwaymilyah

Ubayriq

Dibdibah

Liyah

Gudhi
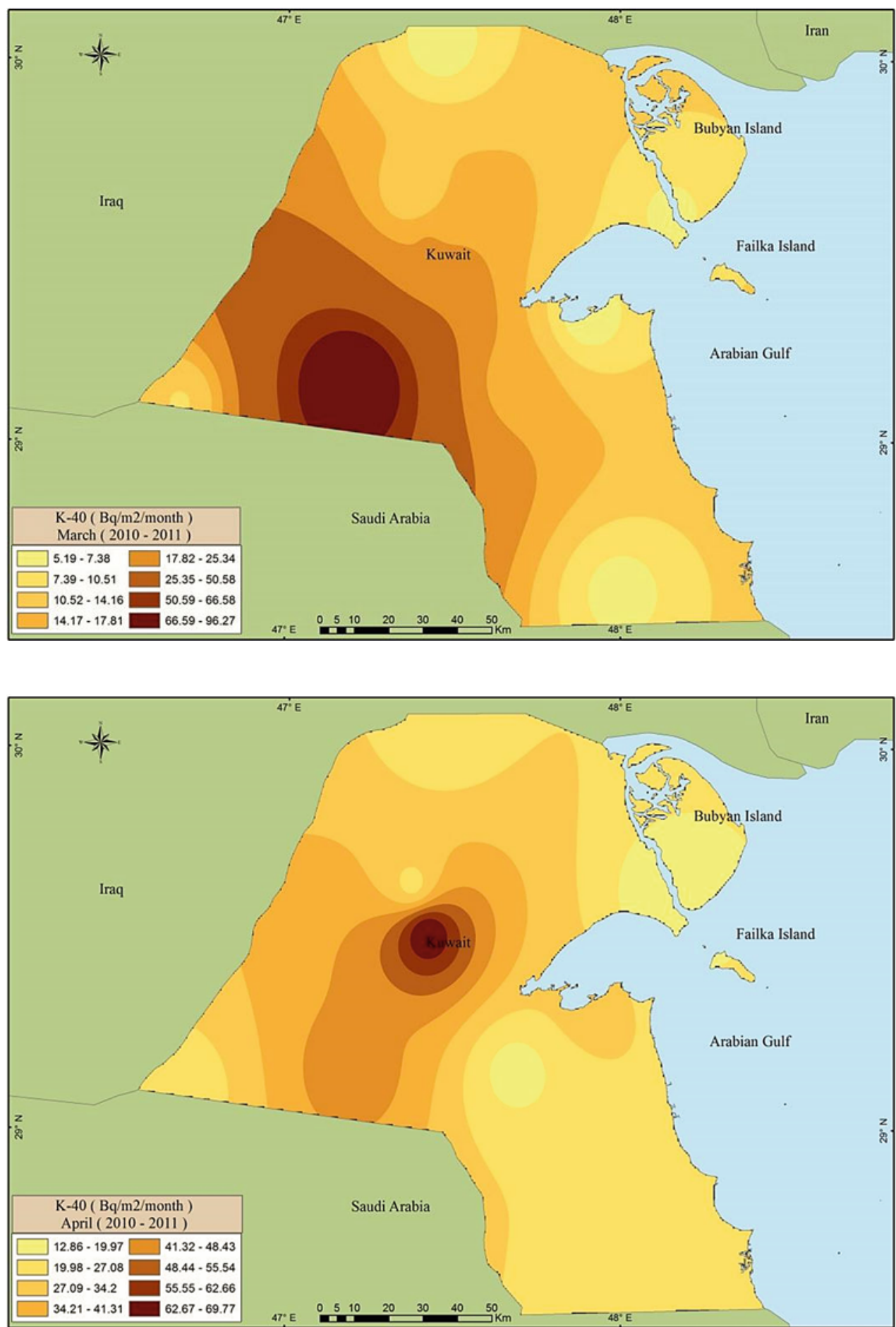

Areas with low radionuclide concentration

Abdulli

Subiyah

Wafra Farms

Shuaiba

Bubiyan Island
The monthly ${ }^{40} \mathrm{~K}$ rates deposited in Kuwait during May 2010-2011 ranged from 5.12 to $70.63 \mathrm{~Bq} \mathrm{~m}^{-2}$, with the maximum in southeastern and central areas. This range is similar to the other spring months, in which the critical dynamics weather due to Koss and Sarrayat contributed toward high deposition rates. The lowest deposition fluxes were in southern and eastern areas. However, the high 
Fig. 6.34 Average deposited rates of ${ }^{40} \mathrm{~K}$ in May (2009-2010)

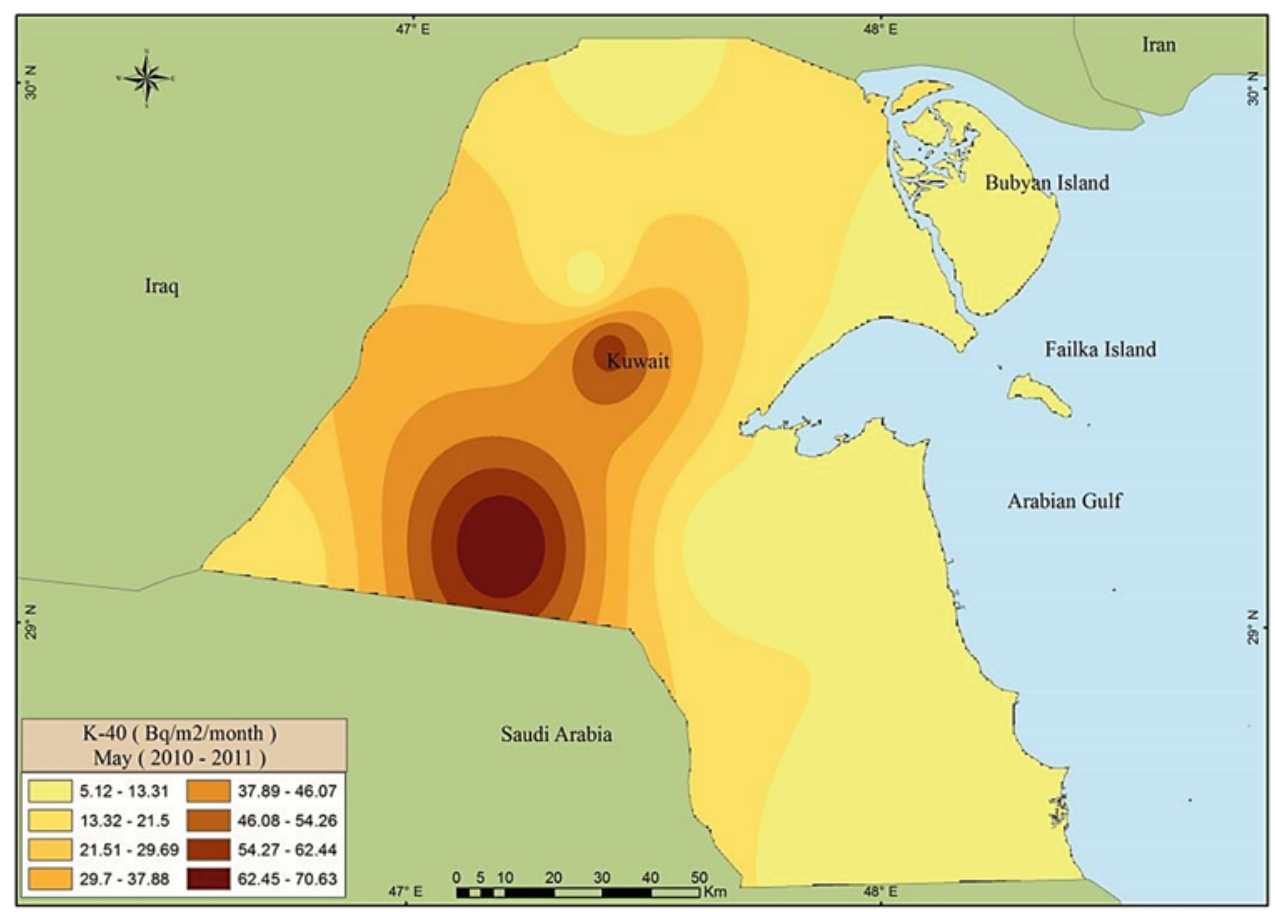

deposition flux this month was due to the effect of the exotic storm that hit Kuwait on March 25, 2011 (Fig. 6.34).

\begin{tabular}{l|l}
\hline $\begin{array}{l}\text { Areas with high radionuclide } \\
\text { concentration }\end{array}$ & $\begin{array}{l}\text { Areas with low radionuclide } \\
\text { concentration }\end{array}$ \\
\hline Huwaymilyah & Abdulli \\
Ubayriq & Jal Al Zur \\
Dibdibah & Wafra Farms \\
Liyah & Shuaiba \\
Kabd & Bubiyan Island \\
\hline
\end{tabular}

The monthly ${ }^{40} \mathrm{~K}$ deposited rates in Kuwait during June 2010-2011 had similar rates as previous months, but with lower minimum rates, the range varied from 4.53 to $60.43 \mathrm{~Bq} \mathrm{~m}^{-2}$. The maximum rates were in southeastern areas, and the lowest was in coastal areas. The predominant wind direction for this month was northwesterly, with no precipitation events (Fig. 6.35).

\begin{tabular}{l|l}
\hline $\begin{array}{l}\text { Areas with high radionuclide } \\
\text { concentration }\end{array}$ & $\begin{array}{l}\text { Areas with low radionuclide } \\
\text { concentration }\end{array}$ \\
\hline Huwaymilyah & Abdulli \\
Ubayriq & Salmi \\
Dibdibah & Salmiya \\
Liyah & Sulaybiyah \\
Um Qudayr & Kabd \\
\hline
\end{tabular}

The monthly ${ }^{40} \mathrm{~K}$ rates deposited in Kuwait during July 2010-2011 were similar to the other summer months. The range of deposition varied between 2.31 and $61.76 \mathrm{~Bq} \mathrm{~m}^{-2}$. The maximum rates were in southeastern areas, and the lowest rates were in southern and northeastern areas. The predominant wind direction for this month was northwesterly, with no precipitation events or impact wind from other directions (Fig. 6.36).

\begin{tabular}{l|l}
\hline $\begin{array}{l}\text { Areas with high radionuclide } \\
\text { concentration }\end{array}$ & $\begin{array}{l}\text { Areas with low radionuclide } \\
\text { concentration }\end{array}$ \\
\hline Huwaymilyah & Abdulli \\
Ubayriq & Subiyah \\
Dibdibah & Salmiya \\
Liyah & Salmi \\
Um Qudayr & Bubiyan Island \\
\hline
\end{tabular}

The monthly ${ }^{40} \mathrm{~K}$ rates deposited in Kuwait during August 2010-2011 had a similar trend to June and July, with a low range that varied from 2.23 to $27.63 \mathrm{~Bq} \mathrm{~m}^{-2}$, with the maximum in southwestern areas. The predominant wind direction was northwesterly, with a minor contribution made by southeastern wind (Fig. 6.37).

\begin{tabular}{l|l}
\hline $\begin{array}{l}\text { Areas with high radionuclide } \\
\text { concentration }\end{array}$ & $\begin{array}{l}\text { Areas with low radionuclide } \\
\text { concentration }\end{array}$ \\
\hline Huwaymilyah & Abdulli \\
Ubayriq & Salmi \\
Dibdibah & Salmiya \\
Liyah & Sulaybiyah \\
Bubiyan Island & Wafra Farms \\
\hline
\end{tabular}

Similar to the summer months, the monthly ${ }^{40} \mathrm{~K}$ rates deposited in Kuwait during September 2010-2011 ranged from 1.55 to $41.61 \mathrm{~Bq} \mathrm{~m}^{-2}$, with the maximum recorded in southwestern areas and the lowest recorded in northern and central coastal areas. The predominant wind direction in this 
Fig. 6.35 Average deposited rates of ${ }^{40} \mathrm{~K}$ in June (2010-2011)

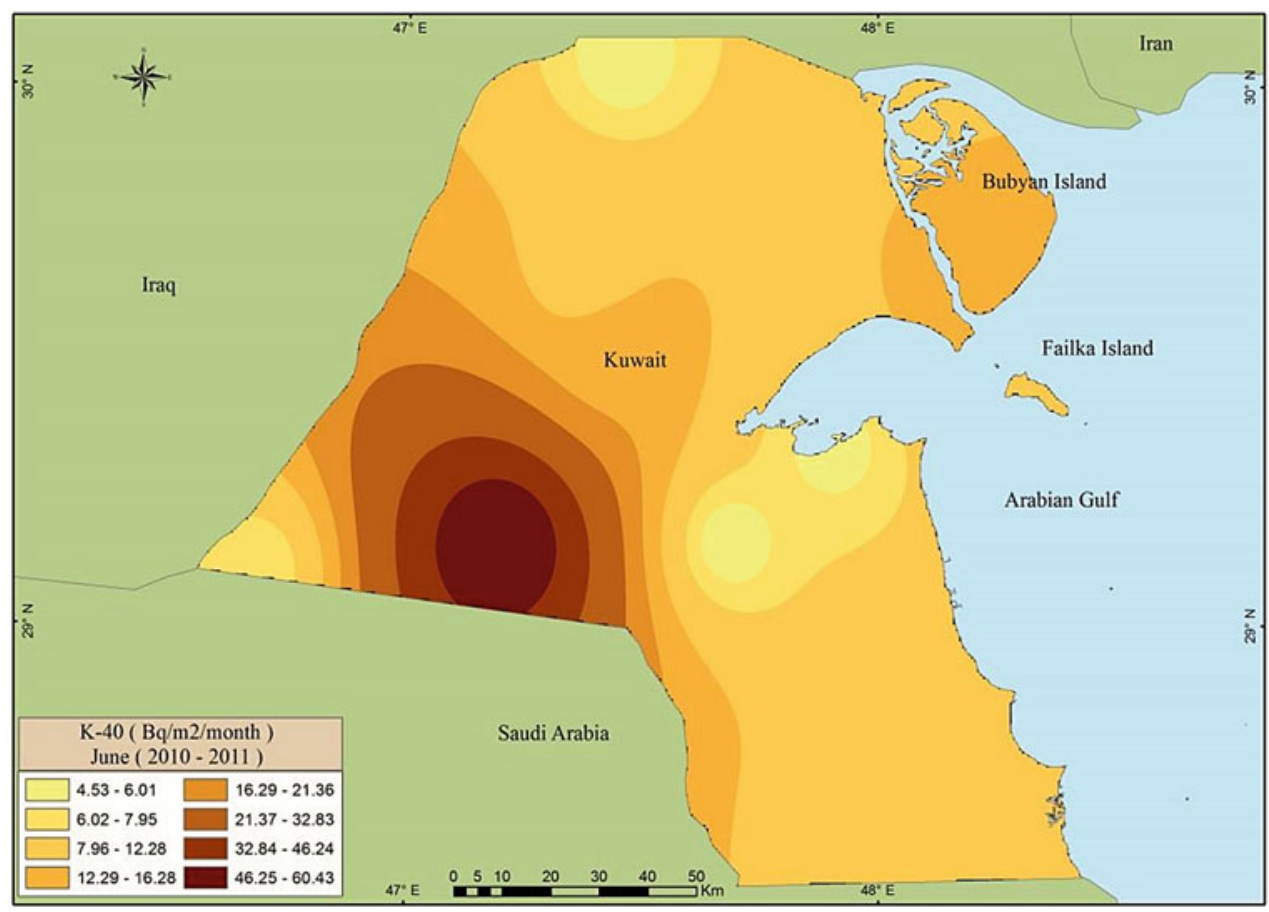

Fig. 6.36 Average deposited rates of ${ }^{40} \mathrm{~K}$ in July (2010-2011)

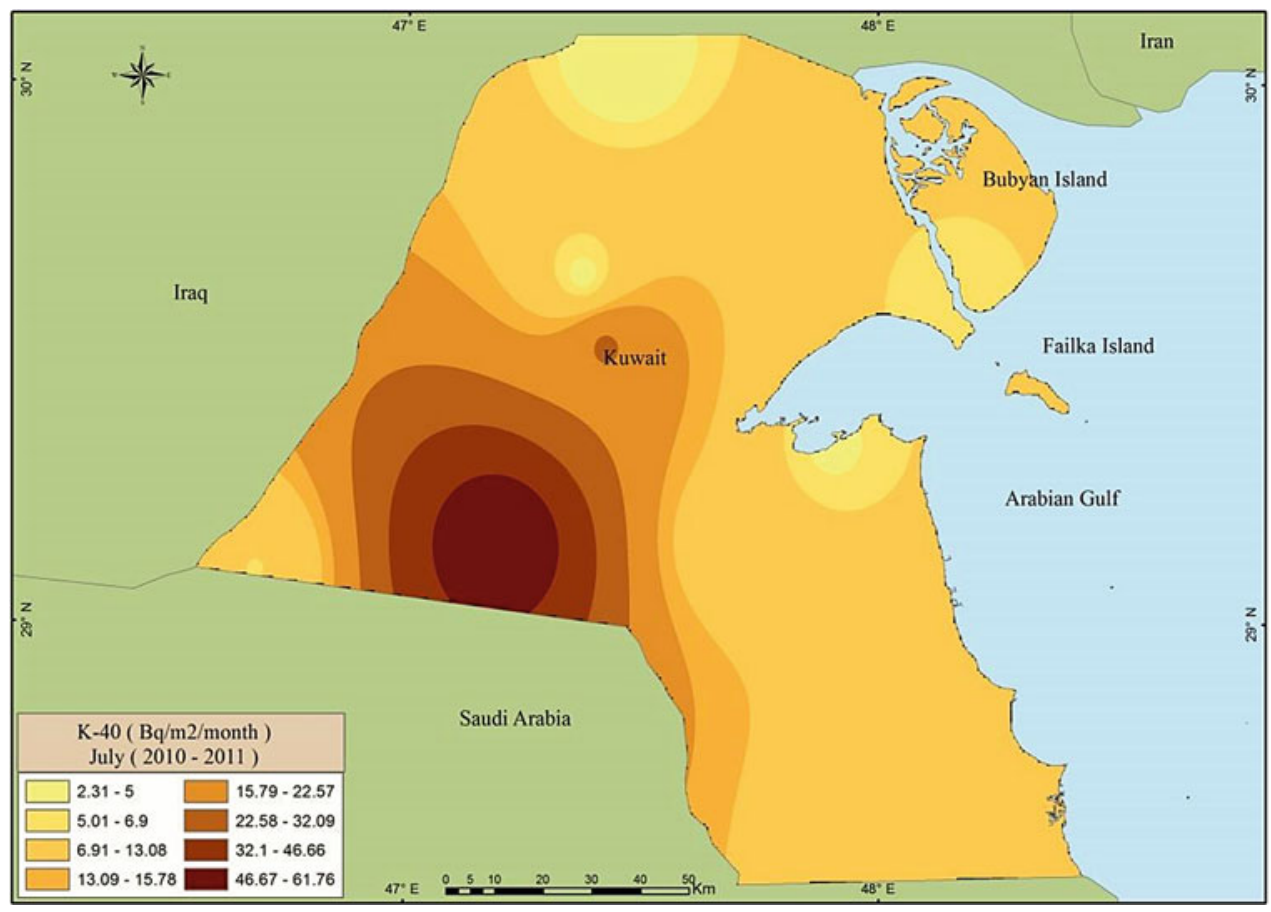


Fig. 6.37 Average deposited rates of ${ }^{40} \mathrm{~K}$ in August (2010 2011)

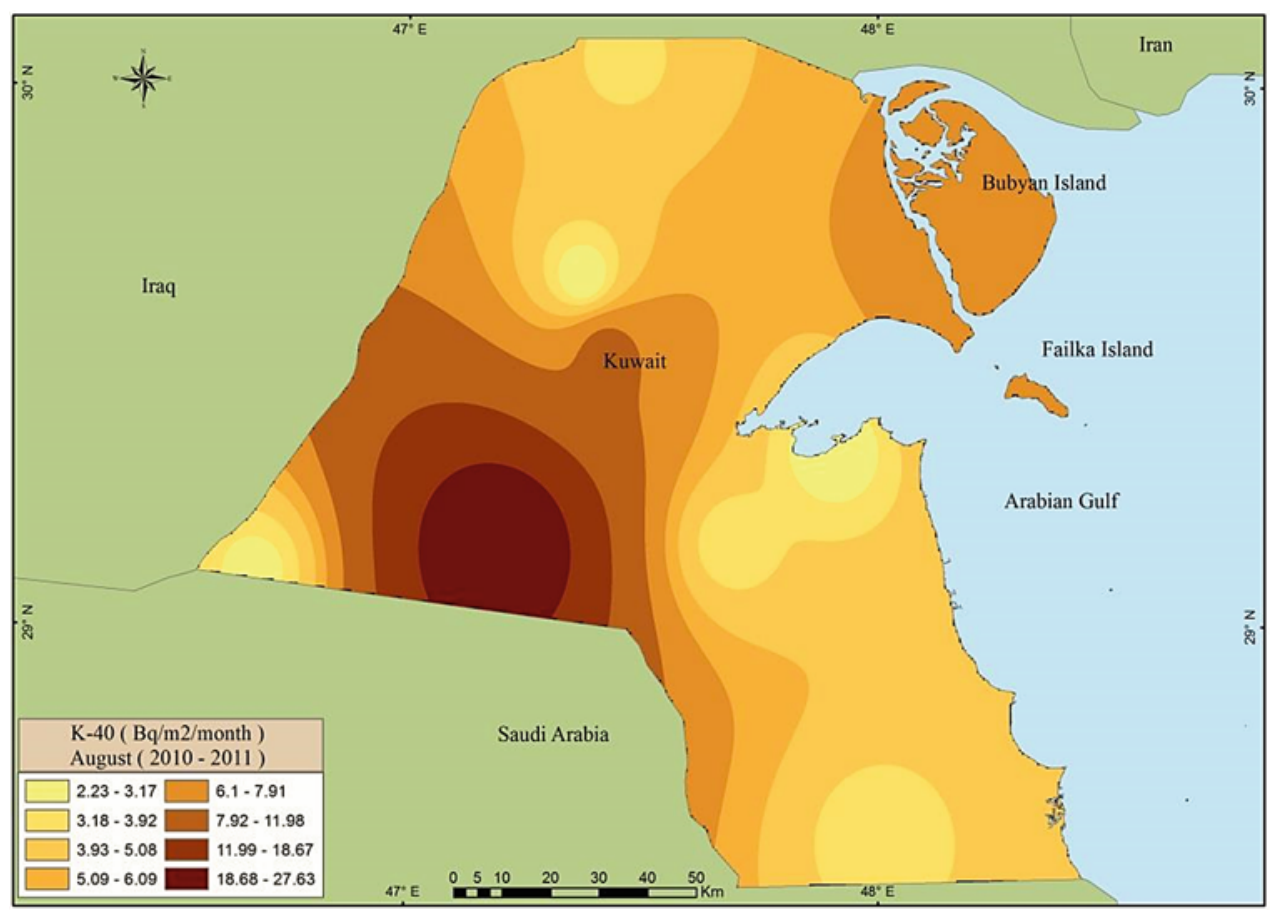

month was northwesterly, with no contribution from other directions (Fig. 6.38).

\begin{tabular}{l|l}
\hline $\begin{array}{l}\text { Areas with high radionuclide } \\
\text { concentration }\end{array}$ & $\begin{array}{l}\text { Areas with low radionuclide } \\
\text { concentration }\end{array}$ \\
\hline Ubayriq & Abdulli \\
Dibdibah & Salmi \\
Liyah & Salmiya \\
Shegaya & Bubiyan Island \\
Huwaymilyah & Wafra Farms \\
\hline
\end{tabular}

Similar to summer, the monthly ${ }^{40} \mathrm{~K}$ rates deposited in Kuwait during October 2010-2011 ranged from 1.56 to $61.32 \mathrm{~Bq} \mathrm{~m}^{-2}$, with the maximum in southwestern areas and the lowest in northern and central eastern areas. The predominant wind direction of this month was northwesterly, with no contribution from other directions (Fig. 6.39).

\begin{tabular}{l|l}
\hline $\begin{array}{l}\text { Areas with high radionuclide } \\
\text { concentration }\end{array}$ & $\begin{array}{l}\text { Areas with low radionuclide } \\
\text { concentration }\end{array}$ \\
\hline Ubayriq & Subiyah \\
Dibdibah & Salmi \\
Liyah & Salmiya \\
Ratqah & Bubiyan Island \\
Huwaymilyah & Wafra Farms \\
\hline
\end{tabular}

The monthly ${ }^{40} \mathrm{~K}$ rates deposited in Kuwait during November 2009-2010 were low, ranging from 1.28 to
21.28 $\mathrm{Bq} \mathrm{m}^{-2}$, with the maximum in the central and southwestern areas and the lowest in the southern and northern areas. The predominant wind direction was northwesterly, with high speed recorded at times (Fig. 6.40).

\begin{tabular}{l|l}
\hline $\begin{array}{l}\text { Areas with high radionuclide } \\
\text { concentration }\end{array}$ & $\begin{array}{l}\text { Areas with low radionuclide } \\
\text { concentration }\end{array}$ \\
\hline Ubayriq & Abdulli \\
Dibdibah & Subiyah \\
Liyah & Salmiya \\
Shegaya & Bubiyan Island \\
Huwaymilyah & Wafra Farms \\
\hline
\end{tabular}

The monthly ${ }^{40} \mathrm{~K}$ rates deposited in Kuwait during December 2009-2010 were moderate and ranged from 1.91 to $31.12 \mathrm{~Bq} \mathrm{~m}^{-2}$, with the maximum in the southwestern areas and the lowest in the southern areas. The predominant wind direction was northwesterly, with high speed at times (Fig. 6.41).

\begin{tabular}{l|l}
\hline $\begin{array}{l}\text { Areas with high radionuclide } \\
\text { concentration }\end{array}$ & $\begin{array}{l}\text { Areas with low radionuclide } \\
\text { concentration }\end{array}$ \\
\hline Ubayriq & Abdulli \\
Dibdibah & Subiyah \\
Liyah & Salmi \\
Shegaya & Bubiyan Island \\
Huwaymilyah & Wafra Farms \\
\hline
\end{tabular}


Fig. 6.38 Average deposited rates of ${ }^{40} \mathrm{~K}$ in September (2010)
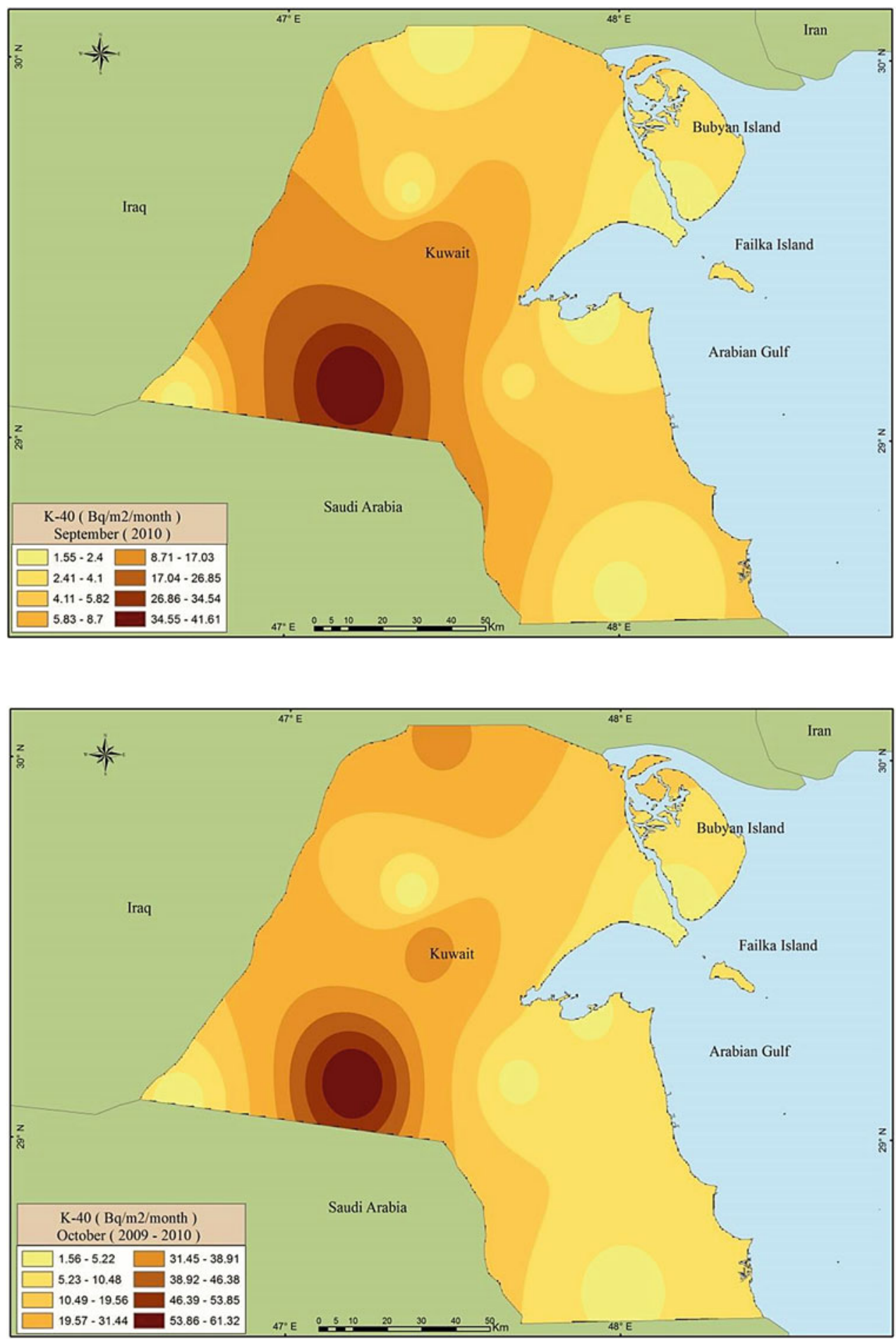

Fig. 6.39 Average deposited rates of ${ }^{40} \mathrm{~K}$ in October (20092010) 
Fig. 6.40 Average deposited rates of ${ }^{40} \mathrm{~K}$ in November (20092010)

Fig. 6.41 Average deposited rates of ${ }^{40} \mathrm{~K}$ in December (20092010)
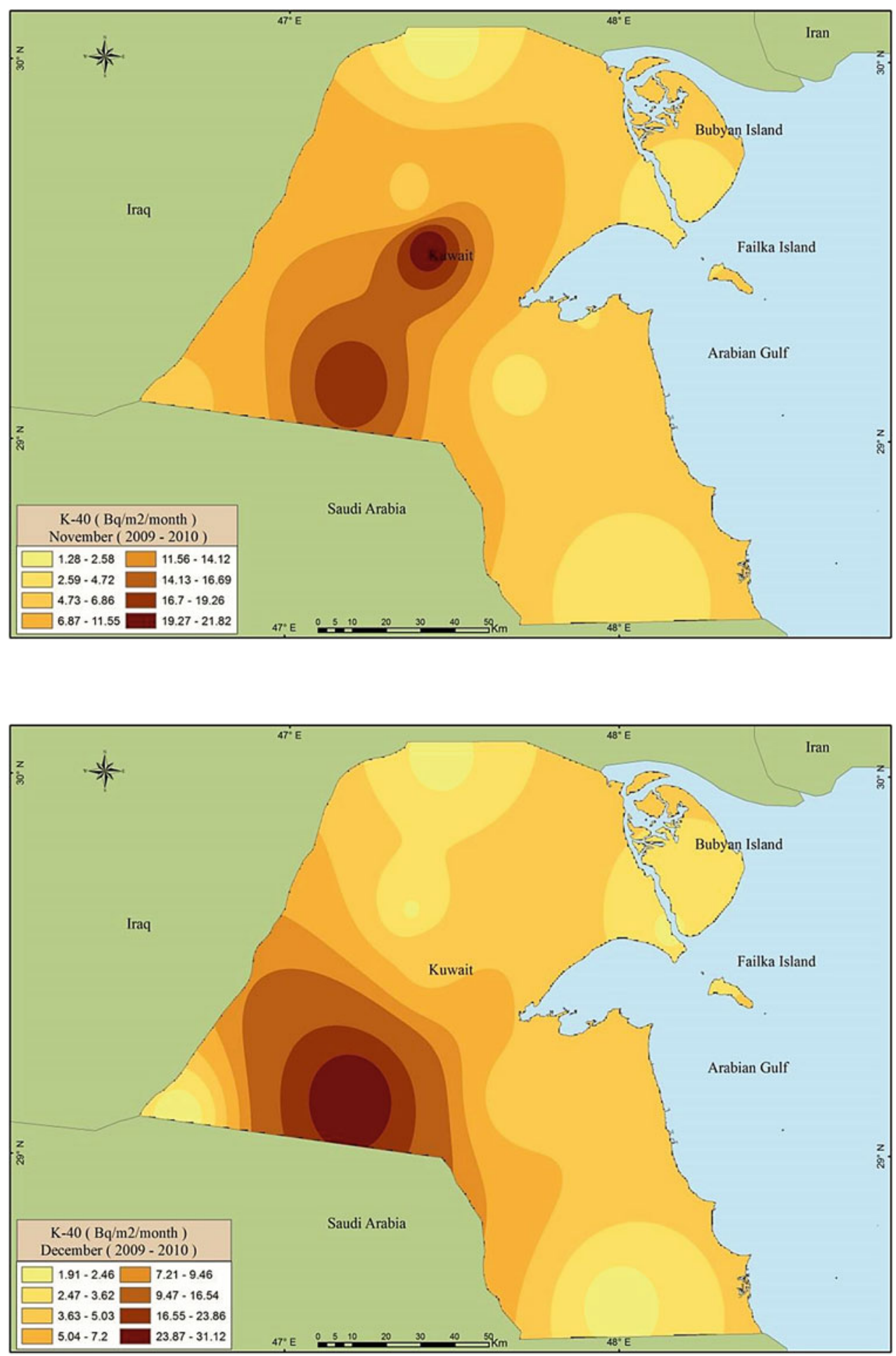

\section{Annual Deposited Rates of ${ }^{210} \mathrm{~Pb}$}

The average annual ${ }^{210} \mathrm{~Pb}$ rates deposited in Kuwait from October 2009 to August 2011 varied from 107 to $233 \mathrm{~Bq} \mathrm{~m}^{-2}$, with an average of about $134 \mathrm{~Bq} \mathrm{~m}^{-2}$, which is close to the reported ${ }^{210} \mathrm{~Pb}$ annual deposition rates on the continent between $10^{\circ}$ and $30^{\circ} \mathrm{N}$ latitude $\left(160 \mathrm{~Bq} \mathrm{~m}^{-2}\right.$ ). The maximum rates were in the southeastern part of the country (Shaqaya). The minimum rates were along the coastal areas. A maximum of ${ }^{210} \mathrm{~Pb}$ deposition flux was revealed in the spring months; when the precipitation was high, the predominant annual wind direction was northwesterly (Fig. 6.42). 
Fig. 6.42 Average deposited rates of ${ }^{210} \mathrm{~Pb}$ in (October 2009August 2011)

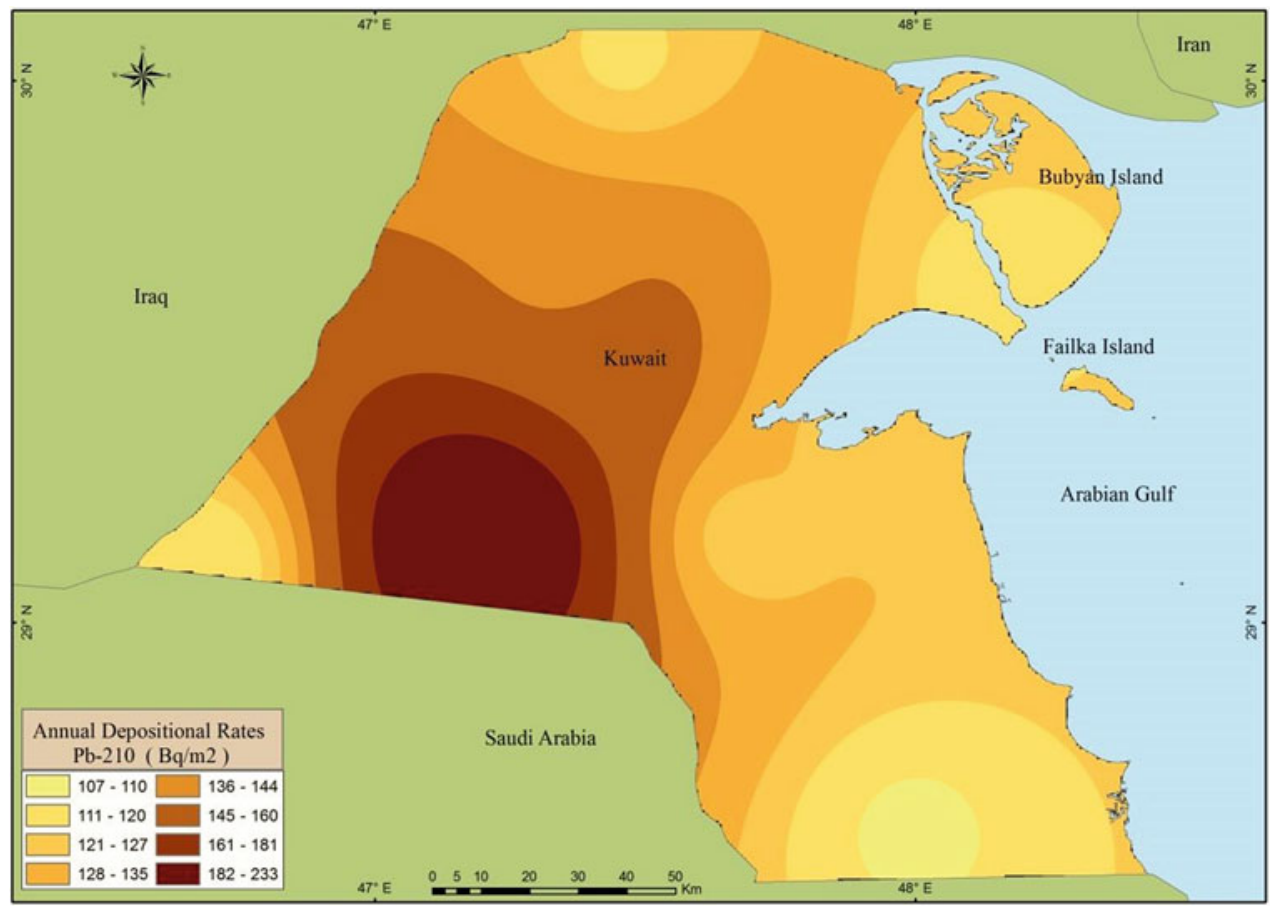

Areas with low radionuclide concentration

\begin{tabular}{l|l} 
concentration & concentration \\
\hline Ubayriq & Abdulli \\
Dibdibah & Subiyah \\
Liyah & Salmi \\
Shegaya & Bubiyan Island \\
Huwaymilyah & Wafra Farms
\end{tabular}

\section{Monthly Deposited Rates of ${ }^{210} \mathrm{~Pb}$}

The monthly ${ }^{210} \mathrm{~Pb}$ deposited rates in Kuwait during January 2010-2011 ranged from 4.9 to $16.73 \mathrm{~Bq} \mathrm{~m}^{-2}$, with the maximum in central areas and the lowest in southern areas. The predominant wind direction for this month was northwesterly (Fig. 6.43).

\begin{tabular}{l|l}
\hline $\begin{array}{l}\text { Areas with high radionuclide } \\
\text { concentration }\end{array}$ & $\begin{array}{l}\text { Areas with low radionuclide } \\
\text { concentration }\end{array}$ \\
\hline Huwaymilyah & Salmi \\
Dibdibah & Sulaybiyah \\
Liyah & KhurFawaris \\
Ratqah & Khiran \\
Um Al Madafi & Wafra Farms
\end{tabular}

The monthly ${ }^{210} \mathrm{~Pb}$ rates deposited in Kuwait during February 2010-2011 ranged from 9.39 to $16.6 \mathrm{~Bq} \mathrm{~m}^{-2}$, with three maximum spots. This is possibly visible because of the effect of dust storms this month. The predominant wind direction for this month was northwesterly, and the precipitation rates were lower (Fig. 6.44).

\begin{tabular}{l|l}
\hline $\begin{array}{l}\text { Areas with high radionuclide } \\
\text { concentration }\end{array}$ & $\begin{array}{l}\text { Areas with low radionuclide } \\
\text { concentration }\end{array}$ \\
\hline $\begin{array}{l}\text { Bubiyan Island } \\
\text { Dibdibah }\end{array}$ & Salmi \\
Liyah & Sulaybiyah \\
Ratqah & Liyah \\
Subiyah & Atraf \\
\hline
\end{tabular}

The monthly ${ }^{210} \mathrm{~Pb}$ deposited rates in Kuwait during February 2010-2011 ranged from 9.39 to $16.6 \mathrm{~Bq} \mathrm{~m}^{-2}$, with three maximum spots. This is possibly visible because of the effect of dust storms this month. The predominant wind direction for this month was northwesterly, and the precipitation rates were lower (Fig. 6.45).

\begin{tabular}{l|l}
\hline $\begin{array}{l}\text { Areas with high radionuclide } \\
\text { concentration }\end{array}$ & $\begin{array}{l}\text { Areas with low radionuclide } \\
\text { concentration }\end{array}$ \\
\hline $\begin{array}{l}\text { Huwaymilyah } \\
\text { Dibdibah }\end{array}$ & Salmi \\
Liyah & Subiyah \\
Ubayriq & Ratqah \\
Um Al Madafi & Salmiya \\
\hline
\end{tabular}

The monthly ${ }^{210} \mathrm{~Pb}$ deposited rates in Kuwait during April 2010-2011 ranged from 22.36 to $41.38 \mathrm{~Bq} \mathrm{~m}^{-2}$. The major parameter affecting this high value was the high precipitation rate. The predominant wind direction was northwesterly, 
Fig. 6.43 Average deposited rates of ${ }^{210} \mathrm{~Pb}$ in January (20102011)

Fig. 6.44 Average deposited rates of ${ }^{210} \mathrm{~Pb}$ in February (2010 2011)
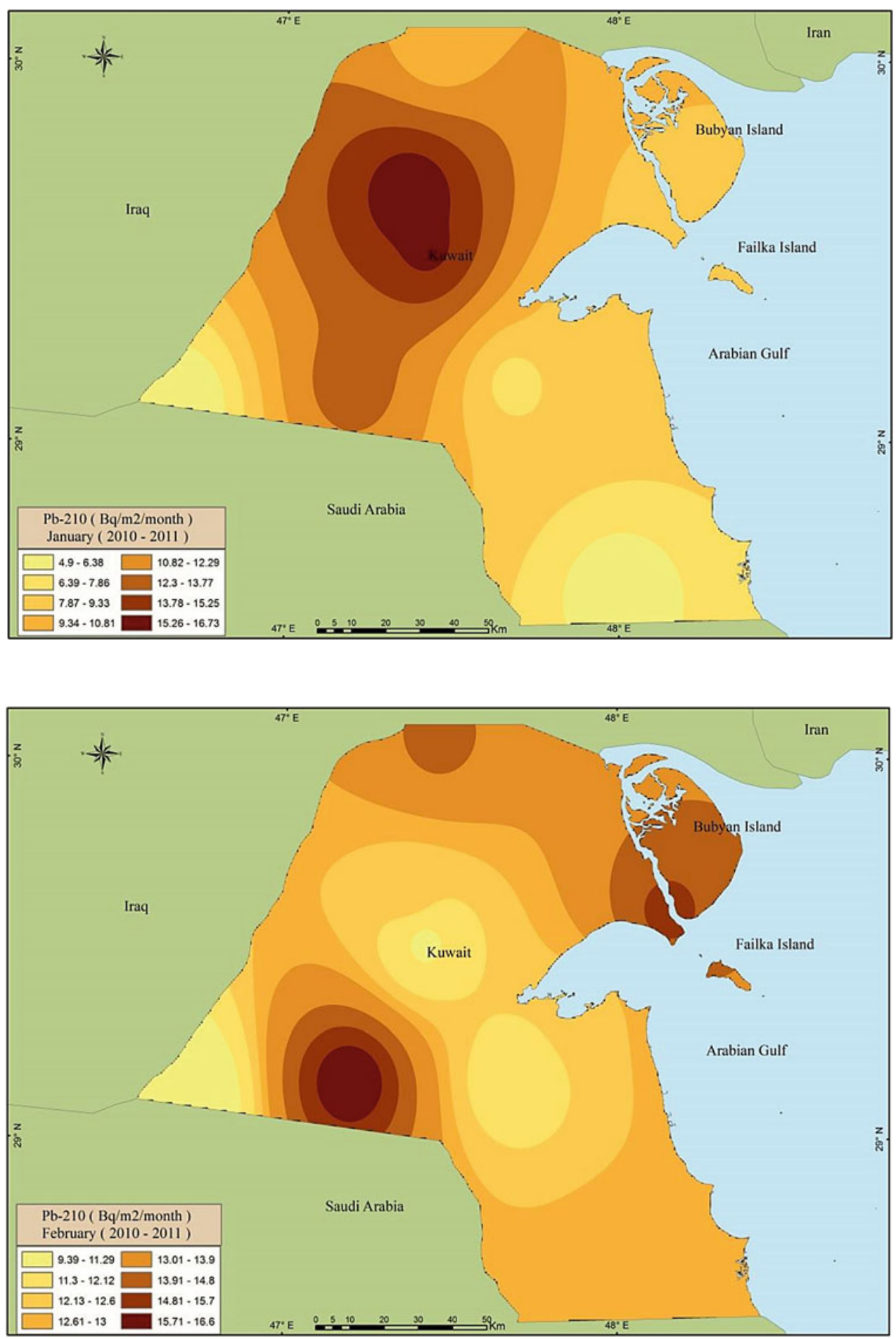
Fig. 6.45 Average deposited rates of ${ }^{210} \mathrm{~Pb}$ in March $(2010$ 2011)

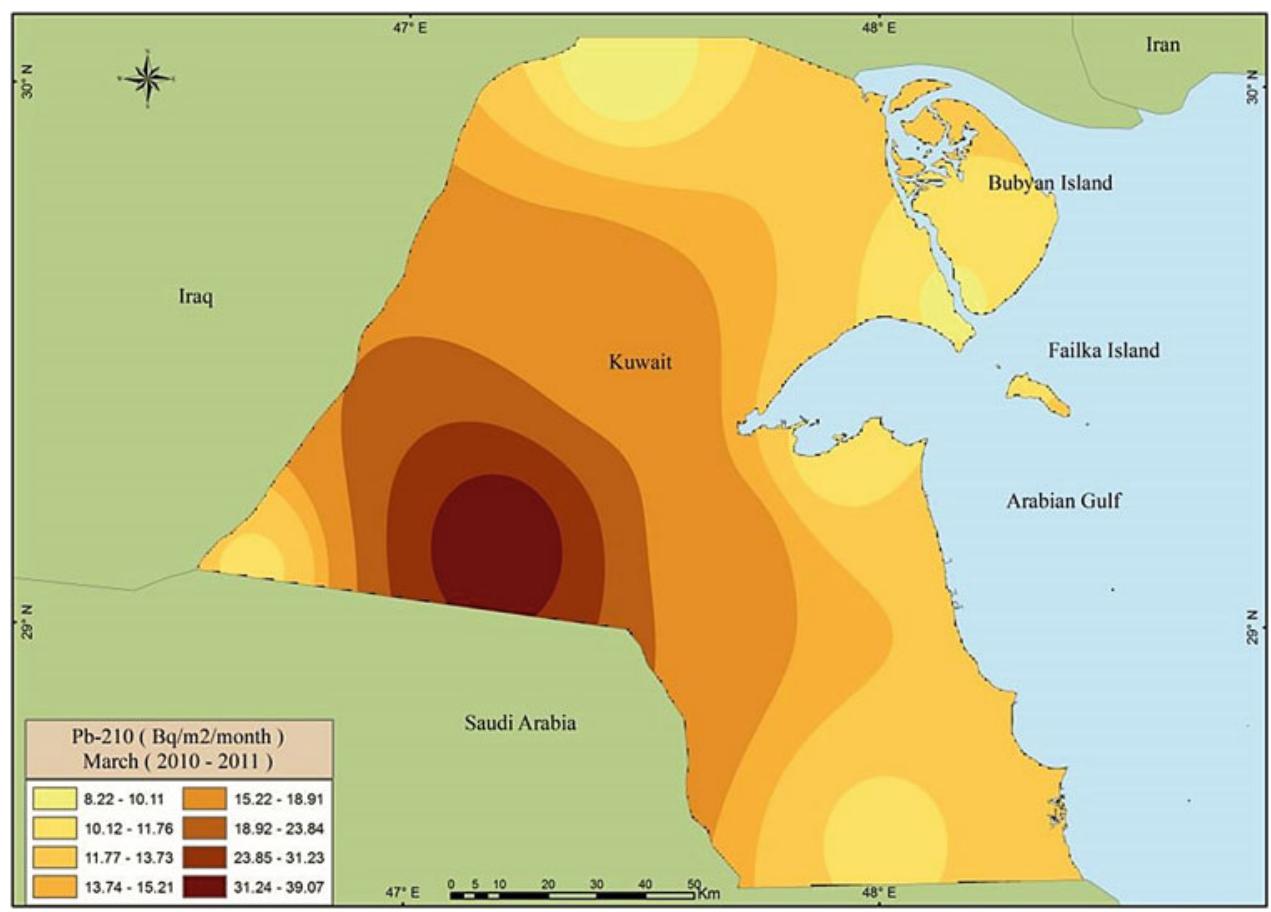

with a high wind speed of northeastern, eastern, and southeastern wind contribution (Fig. 6.46).

\section{Areas with high radionuclide concentration}

Liyah

Huwaymilyah
Areas with low radionuclide concentration

Salmi

Sulaybiyah
Areas with high radionuclide concentration

\section{Dibdibah}

Ratqah

Doha

The monthly ${ }^{210} \mathrm{~Pb}$ rates deposited in Kuwait during May 2010-2011 ranged from 8.19 to $30.44 \mathrm{~Bq} \mathrm{~m}^{-2}$, with the
Fig. 6.46 Average deposited rates of ${ }^{210} \mathrm{~Pb}$ in April (2010 2011)

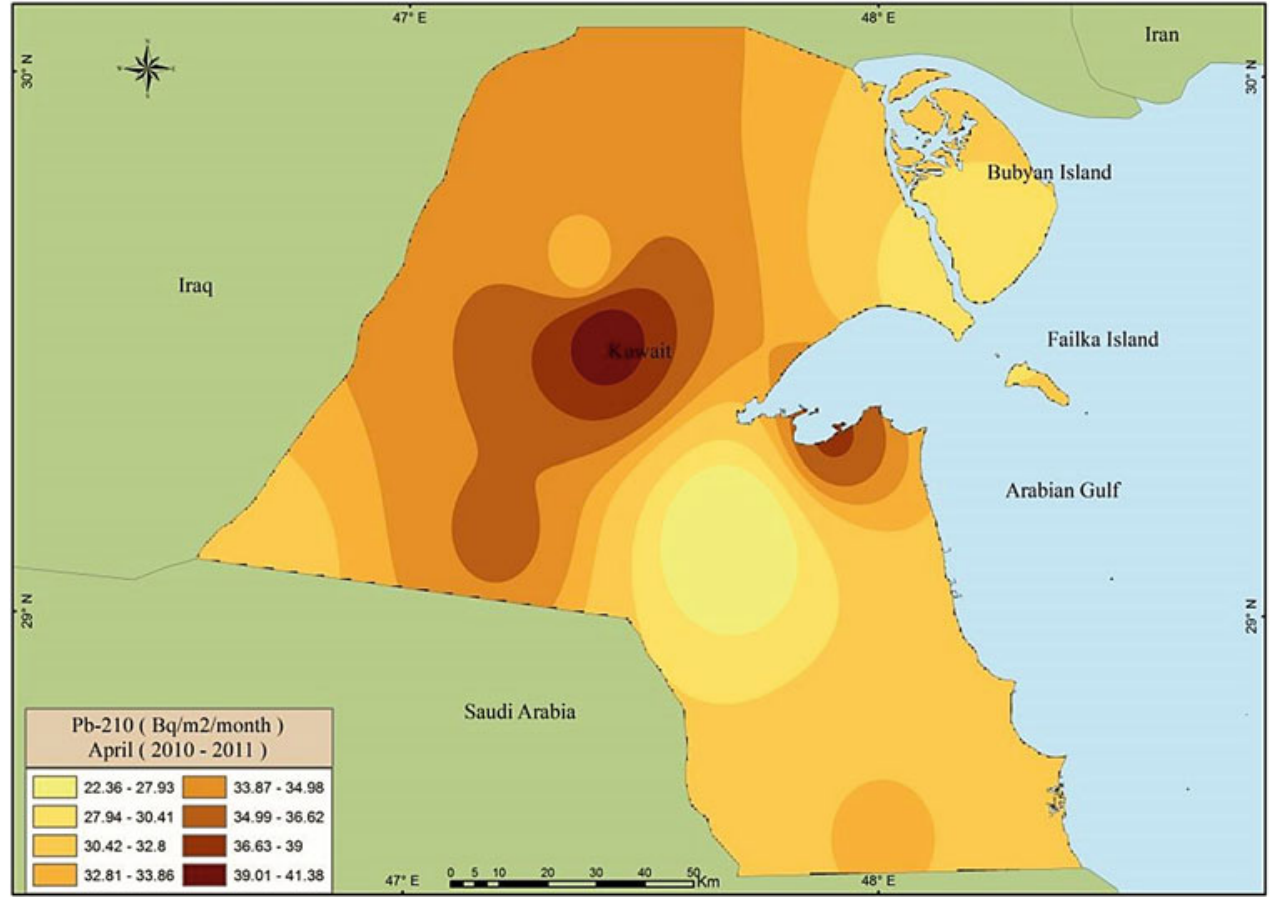


Fig. 6.47 Average deposited rates of ${ }^{210} \mathrm{~Pb}$ in May $(2010$ 2011)

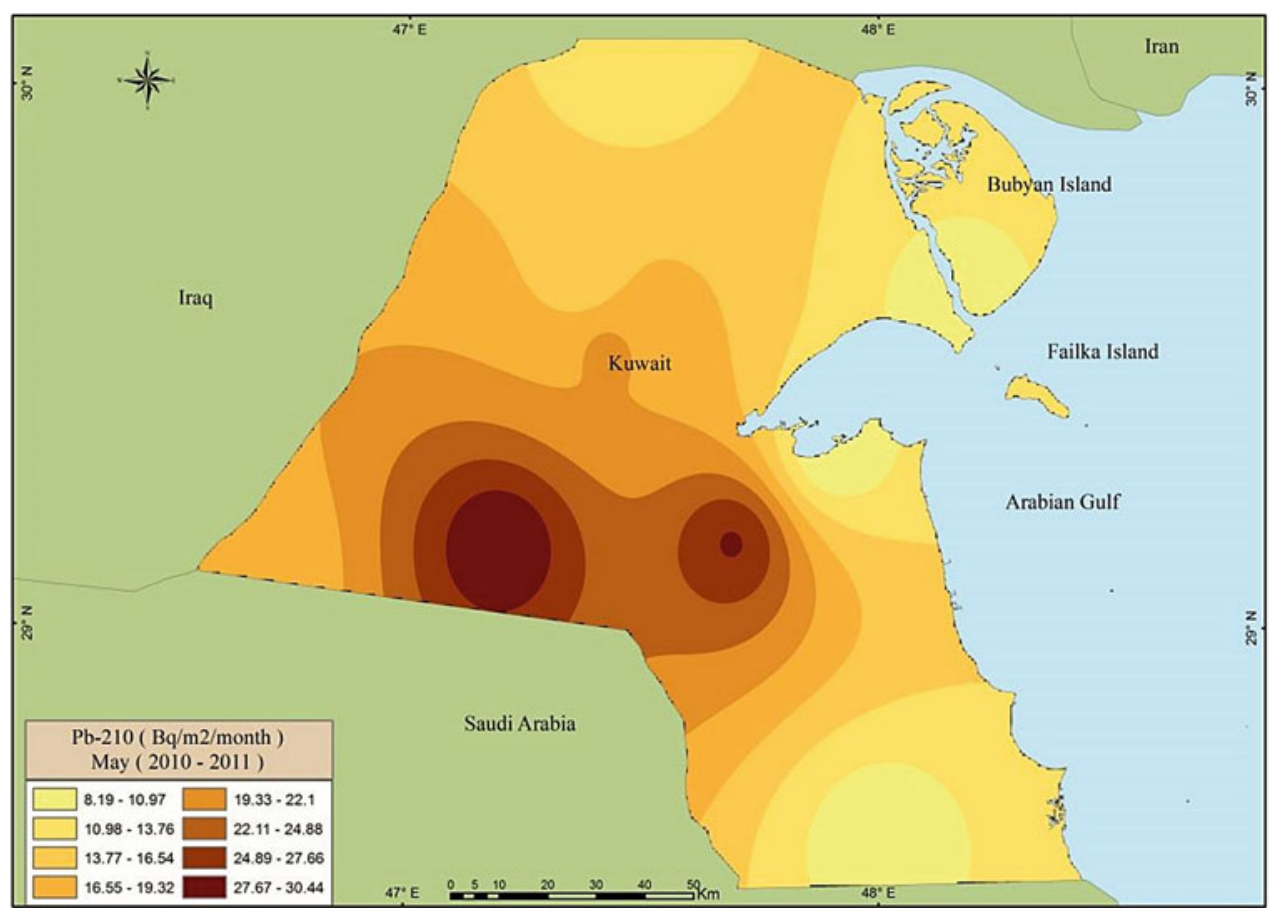

maximum in the southeastern and central areas. The lowest deposition fluxes were in the southern and eastern areas. However, the slightly high deposition flux in this month was because of the effect of the exotic that storm hit Kuwait on March 25, 2011 (Fig. 6.47).

\begin{tabular}{l|l}
\hline $\begin{array}{l}\text { Areas with high radionuclide } \\
\text { concentration }\end{array}$ & $\begin{array}{l}\text { Areas with low radionuclide } \\
\text { concentration }\end{array}$ \\
\hline Huwaymilyah & Doha \\
Dibdibah & Subiyah \\
Liyah & Ratqah \\
Ubayriq & Salmiya \\
Kabd & Wafra Farms
\end{tabular}

The monthly ${ }^{210} \mathrm{~Pb}$ rates deposited in Kuwait during June 2010-2011 were lower compared with previous months, with a range from 4.17 to $20.2 \mathrm{~Bq} \mathrm{~m}^{-2}$. The maximum rates were in the southeastern areas and the lowest in the central areas. The predominant wind direction for this month was northwesterly, with no precipitation events (Fig. 6.48).

\begin{tabular}{l|l}
\hline $\begin{array}{l}\text { Areas with high radionuclide } \\
\text { concentration }\end{array}$ & $\begin{array}{l}\text { Areas with low radionuclide } \\
\text { concentration }\end{array}$ \\
\hline Huwaymilyah & Doha \\
Dibdibah & Sulaybiyah \\
Liyah & Ratqah \\
Ubayriq & Salmi \\
Bubiyan Island & Wafra Farms \\
\hline
\end{tabular}

Similar to June, the monthly ${ }^{210} \mathrm{~Pb}$ deposited rates in Kuwait during July 2010-2011 were lower when compared with previous months. The range of deposition fluxes varied between 3.09 and $15.48 \mathrm{~Bq} \mathrm{~m}^{-2}$. The maximum rates were in the northeastern areas and the lowest in the southern and northeastern areas. The predominant wind direction for this month was northwesterly, with no precipitation events or impact wind from other directions (Fig. 6.49).

\begin{tabular}{l|l}
\hline $\begin{array}{l}\text { Areas with high radionuclide } \\
\text { concentration }\end{array}$ & $\begin{array}{l}\text { Areas with low radionuclide } \\
\text { concentration }\end{array}$ \\
\hline $\begin{array}{l}\text { Huwaymilyah } \\
\text { Dibdibah }\end{array}$ & Doha \\
Liyah & Subiyah \\
Ubayriq & Ratqah \\
Kabd & Salmiya \\
\hline
\end{tabular}

The monthly ${ }^{210} \mathrm{~Pb}$ deposited rates in Kuwait during August 2010-2011 were lower than in June and July, with a range that varied from 2.16 to $9.72 \mathrm{~Bq} \mathrm{~m}^{-2}$, with the maximum in the northern and southwestern areas, and the lowest within the transect along the northwesterly wind corridor (Fig. 6.50).

\begin{tabular}{l|l}
\hline $\begin{array}{l}\text { Areas with high radionuclide } \\
\text { concentration }\end{array}$ & $\begin{array}{l}\text { Areas with low radionuclide } \\
\text { concentration }\end{array}$ \\
\hline $\begin{array}{l}\text { Huwaymilyah } \\
\text { Dibdibah }\end{array}$ & Doha \\
Ratqah & Sulaybiyah \\
Ubayriq & Um Al Madafi \\
Bubiyan Island & Salmi \\
\hline
\end{tabular}

Similar to the summer months, the monthly ${ }^{210} \mathrm{~Pb}$ deposited rates in Kuwait during September 2010-2011 had low rates that ranged from 1.8 to $10.64 \mathrm{~Bq} \mathrm{~m}^{-2}$, with the 
Fig. 6.48 Average deposited rates of ${ }^{210} \mathrm{~Pb}$ in June (20102011)

Fig. 6.49 Average deposited rates of ${ }^{210} \mathrm{~Pb}$ in July (20102011)
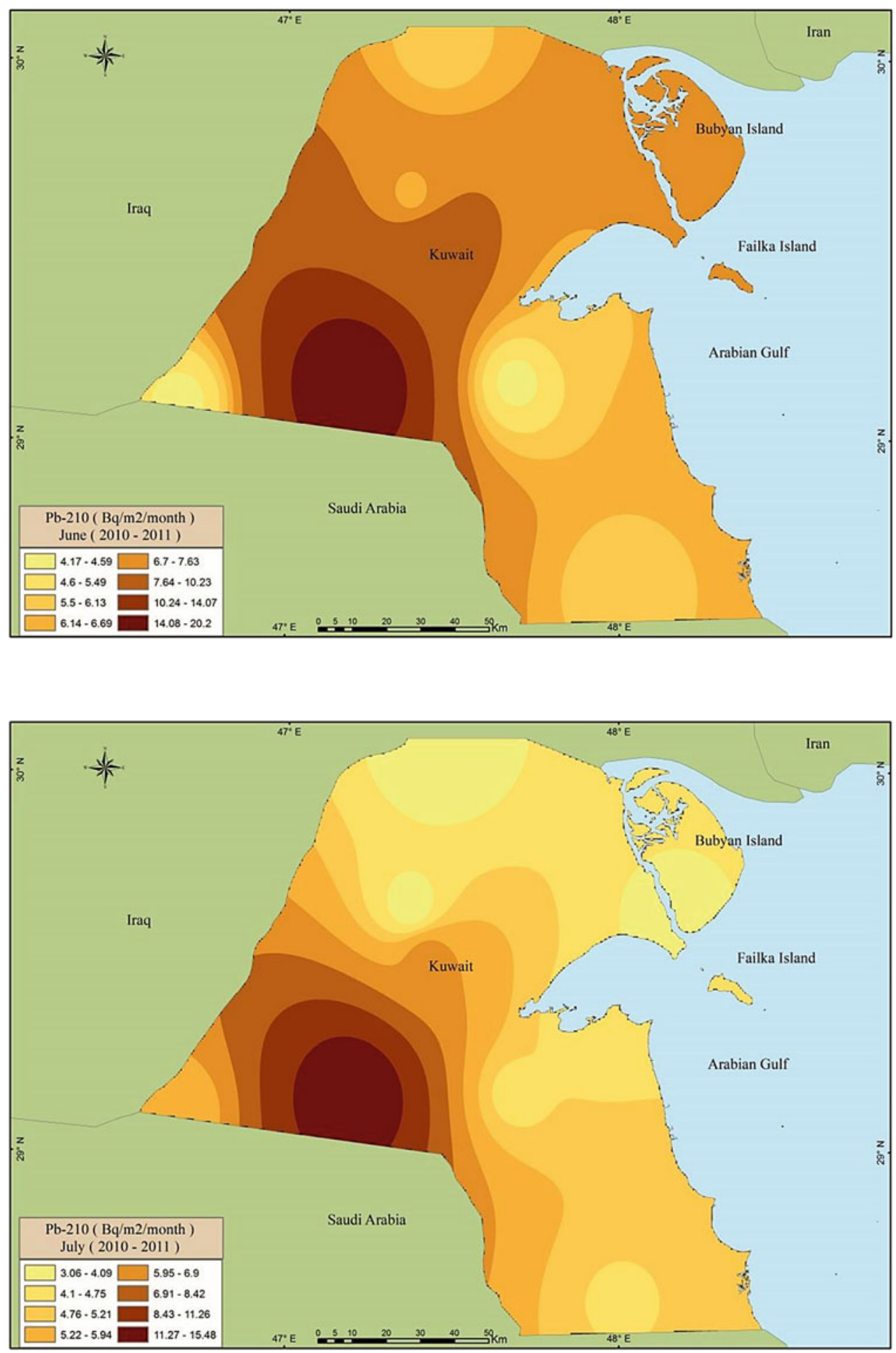
Fig. 6.50 Average deposited rates of ${ }^{210} \mathrm{~Pb}$ in August (20102011)

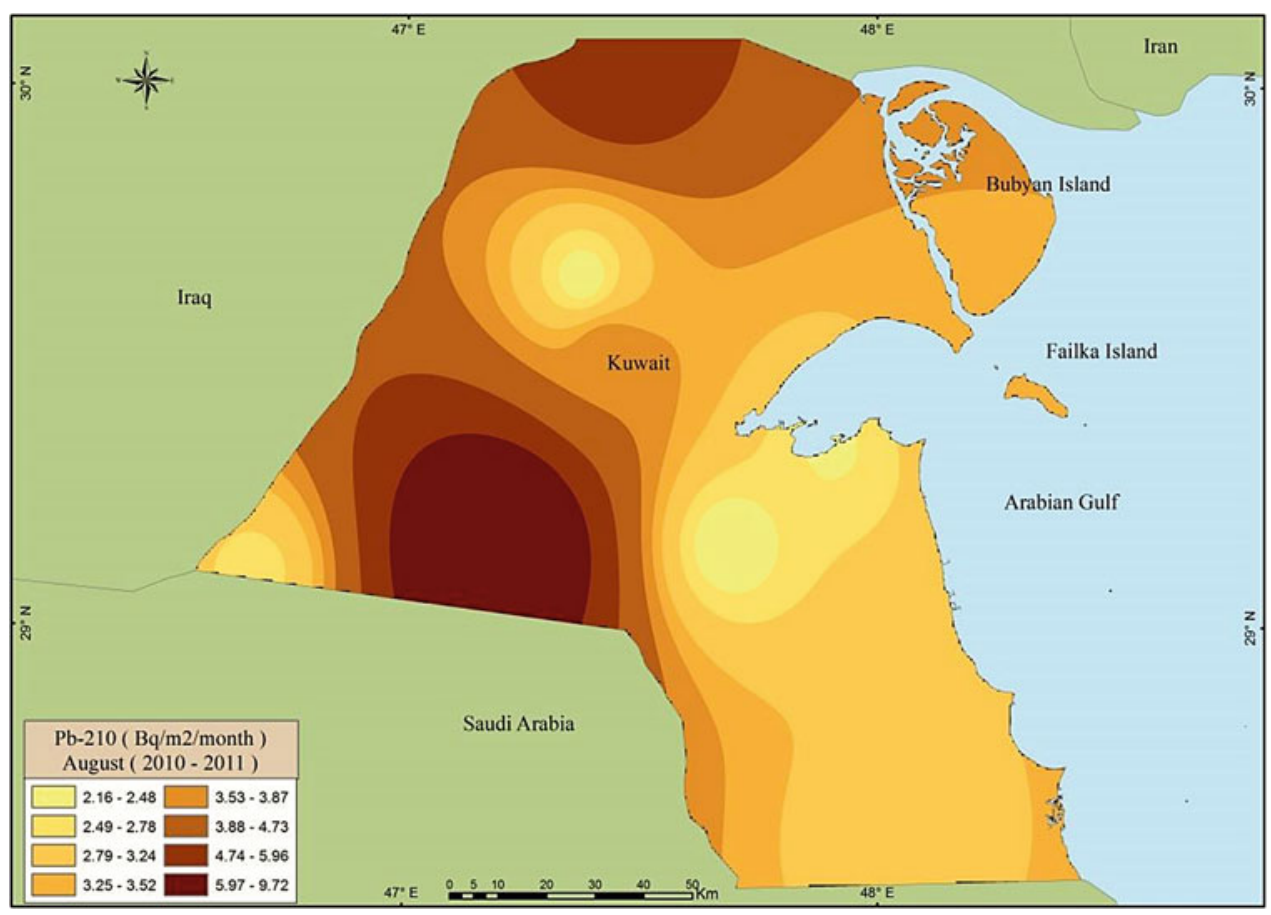

maximum in the northwestern areas and the lowest in the southern and southwestern areas. The predominant wind direction in this month was northwesterly, with no contribution from other directions (Fig. 6.51).

\begin{tabular}{l|l}
\hline $\begin{array}{l}\text { Areas with high radionuclide } \\
\text { concentration }\end{array}$ & $\begin{array}{l}\text { Areas with low radionuclide } \\
\text { concentration }\end{array}$ \\
\hline Huwaymilyah & Doha \\
Dibdibah & Sulaybiyah \\
Liyah & Failaka Island \\
Ubayriq & Salmi \\
Kabd & Wafra Farms \\
\hline
\end{tabular}

Similar to the summer months, the monthly ${ }^{210} \mathrm{~Pb}$ deposited rates in Kuwait during October 2009-2010 showed low rates, with a range that varied from 2.52 to $8.74 \mathrm{~Bq} \mathrm{~m}^{-2}$, with the maximum in the southeastern and northern areas and the lowest along the northwesterly wind corridor (Fig. 6.52).

\begin{tabular}{l|l}
\hline $\begin{array}{l}\text { Areas with high radionuclide } \\
\text { concentration }\end{array}$ & $\begin{array}{l}\text { Areas with low radionuclide } \\
\text { concentration }\end{array}$ \\
\hline Abdulli & Doha \\
Dibdibah & Sulaybiyah \\
Ratqah & Um Al Madafi \\
Ubayriq & Khiran \\
Shegaya & Wafra Farms \\
\hline
\end{tabular}

The monthly ${ }^{210} \mathrm{~Pb}$ deposited rates in Kuwait during November 2009-2010 were moderate, ranging from 5.25 to
14.2 $\mathrm{Bq} \mathrm{m}^{-2}$, with the maximum in the central and southeastern areas and the lowest in the southern areas. The predominant wind direction was northwesterly at a minimum speed (Fig. 6.53).

\begin{tabular}{l|l}
\hline $\begin{array}{l}\text { Areas with high radionuclide } \\
\text { concentration }\end{array}$ & $\begin{array}{l}\text { Areas with low radionuclide } \\
\text { concentration }\end{array}$ \\
\hline Huwaymilyah & Abdulli \\
Dibdibah & Sulaybiyah \\
Doha & Ratqah \\
Ubayriq & Salmi \\
Bubiyan Island & Wafra Farms \\
\hline
\end{tabular}

The monthly ${ }^{210} \mathrm{~Pb}$ rates deposited in Kuwait during December 2009-2010 were similar to November. The rates varied from 4.74 to $14.06 \mathrm{~Bq} \mathrm{~m}^{-2}$, with the maximum in the southwestern and central eastern areas. The predominant wind direction was northwesterly, with high speed at times (Fig. 6.54).

\begin{tabular}{l|l}
\hline $\begin{array}{l}\text { Areas with high radionuclide } \\
\text { concentration }\end{array}$ & $\begin{array}{l}\text { Areas with low radionuclide } \\
\text { concentration }\end{array}$ \\
\hline Doha & Ratqah \\
Dibdibah & Sulaybiyah \\
Ratqah & Salmi \\
Ubayriq & Khiran \\
Um Al Madafi & Wafra Farms
\end{tabular}


Fig. 6.51 Average deposited rates of ${ }^{210} \mathrm{~Pb}$ in September (2010)

Fig. 6.52 Average deposited rates of ${ }^{210} \mathrm{~Pb}$ in October (20092010)
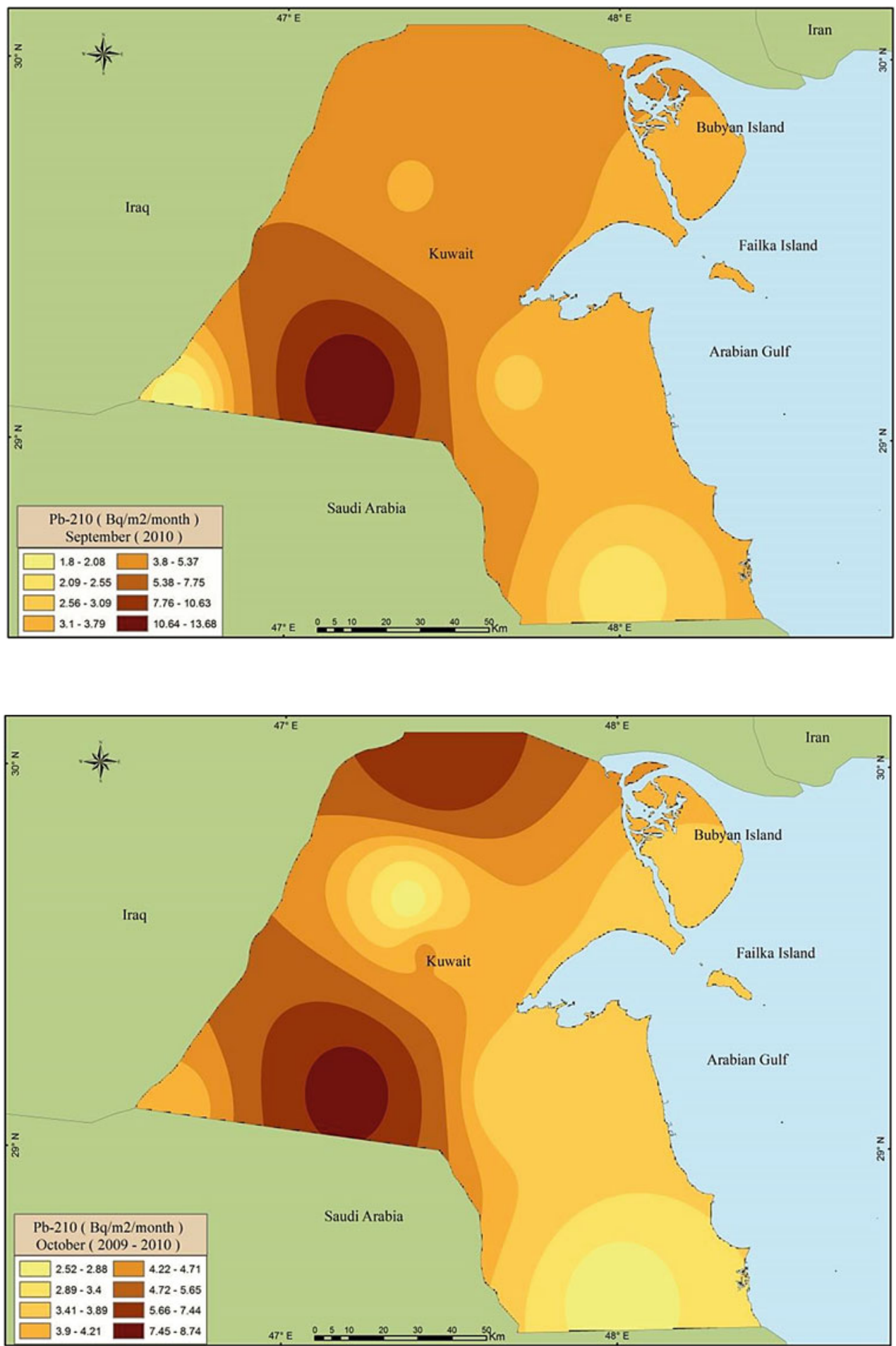
Fig. 6.53 Average deposited rates of ${ }^{210} \mathrm{~Pb}$ in November (2009-2010)

Fig. 6.54 Average deposited rates of ${ }^{210} \mathrm{~Pb}$ in December (2009-2010)
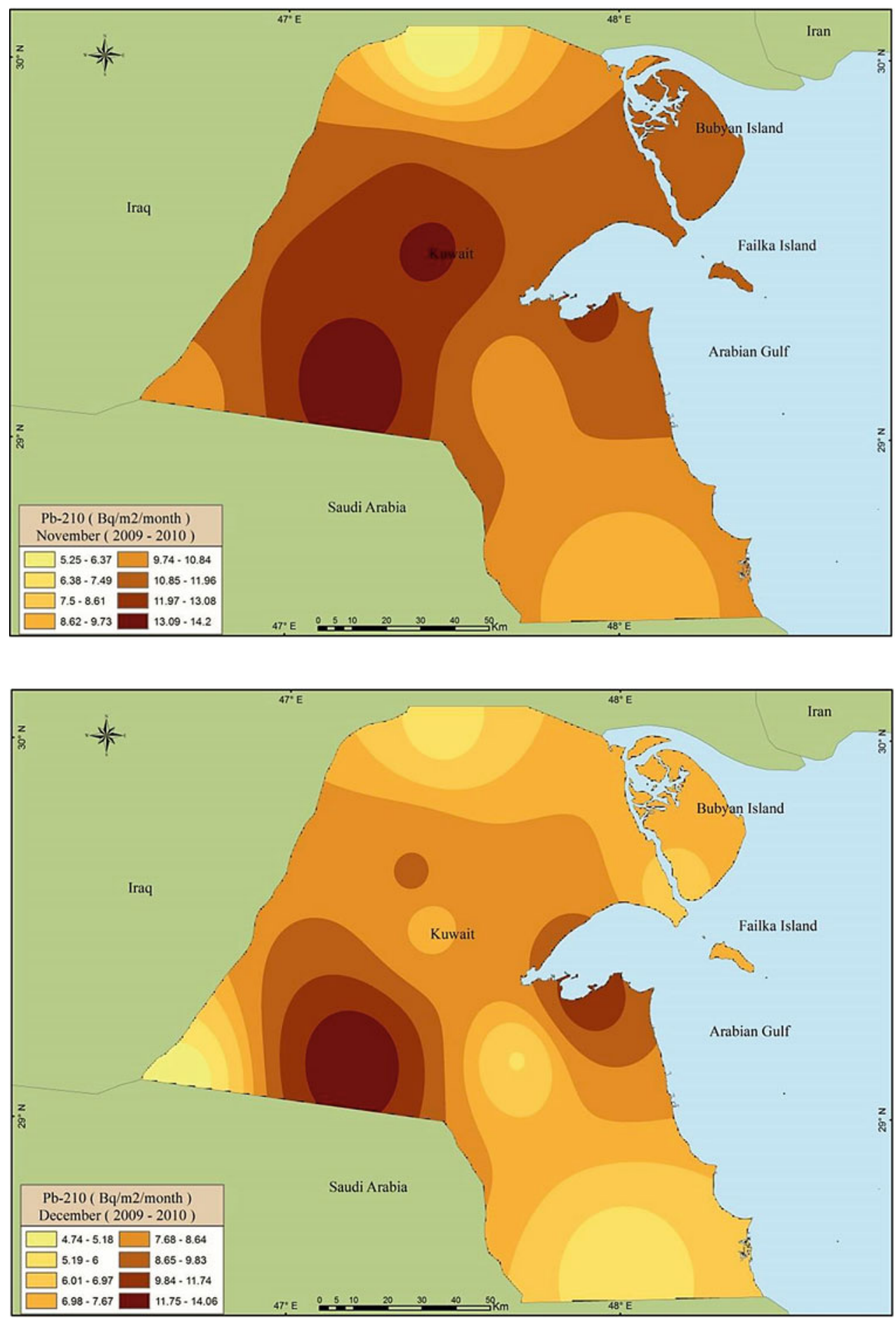

\section{References}

Aba, A., Al-Dousari, A. M., \& Ismaeel, A. (2016). Depositional characteristics of ${ }^{7} \mathrm{Be}$ and ${ }^{210} \mathrm{~Pb}$ in Kuwaiti dust. Journal of Radioanalytical and Nuclear Chemistry, 307(1), 15-23. https://doi. org/10.1007/s10967-015-4129-y.

Aba, A., Al-Dousari, A. M., \& Ismaeel, A. (2018). Atmospheric deposition fluxes of ${ }^{137} \mathrm{Cs}$ associated with dust fallout in the northeastern Arabian Gulf. Journal of Environmental Radioactivity, 192, 565-572. https://doi.org/10.1016/j.jenvrad.2018.05.010.

Al-Dousari, A. M., Aba, A., Al-Awadhi, S., Ahmed, M., \& Al-Dousari, N. (2016). Temporal and spatial assessment of pollen, radionuclides, minerals and trace elements in posited dust within Kuwait. Arabian Journal of Geosciences. https://doi.org/10.1007/s12517015-2182-z.

Biegalski, S., Hosticka, B., \& Mason, L. (2001). Cesium-137 concentrations, trends, and sources observed in Kuwait city, 
Kuwait. Journal of Radioanalytical and Nuclear Chemistry, 248(3), 643-649. https://doi.org/10.1023/A:1010676208657.

Daish, S., Dale, A., Dale, C., May, R., \& Rowe, J. (2005). The temporal variations of ${ }^{7} \mathrm{Be},{ }^{210} \mathrm{~Pb}$ and ${ }^{210} \mathrm{Po}$ in air in England. Journal of Environmental Radioactivity, 84, 457-467. https://doi.org/10.1016/ j.jenvrad.2005.05.003.

Kritz, M. A., Rosner, S. W., Danielsen, E. F., \& Selkirk, H. B. (1991). Air mass origins and troposphere-to-stratosphere exchange associated with mid-latitude cyclogenesis and tropopause folding inferred from ${ }^{7} \mathrm{Be}$ measurements. Journal of Geophysical Research: Atmospheres (1984-2012), 96, 17405-17414. https://doi.org/10.1029/ 91JD01358.
UNSCEAR. (2000). Sources and effects of ionizing radiation: Sources Annex X C: A exposures to the public from man-made sources of radiation.

Viezee, W., \& Singh, H. B. (1980). The distribution of beryllium-7 in the troposphere: Implications on stratospheric/tropospheric air exchange. Geophysical Research Letters, 7. https://doi.org/10. 1029/g1007i010p00805. ISSN: 0094-8276.

Walling, D. E. (2002). Recent advances in the use of environmental radionuclides in soil erosion investigations. In Nuclear techniques in integrated plant nutrient, water and soil management (pp. 279301). RN:33034207.
Open Access This chapter is licensed under the terms of the Creative Commons Attribution 4.0 International License (http:// creativecommons.org/licenses/by/4.0/), which permits use, sharing, adaptation, distribution and reproduction in any medium or format, as long as you give appropriate credit to the original author(s) and the source, provide a link to the Creative Commons licence and indicate if changes were made.
The images or other third party material in this chapter are included in the chapter's Creative Commons licence, unless indicated otherwise in a credit line to the material. If material is not included in the chapter's Creative Commons licence and your intended use is not permitted by statutory regulation or exceeds the permitted use, you will need to obtain permission directly from the copyright holder. 